Report of Investigation 2018-4

\title{
FRACTURE INTENSITY OF THE MESOZOIC SEDIMENTARY FOREARC STRATA OF LOWER COOK INLET, ALASKA
}

J.L. Rosenthal, P.M. Betka, R.J. Gillis, and E.S. Nadin
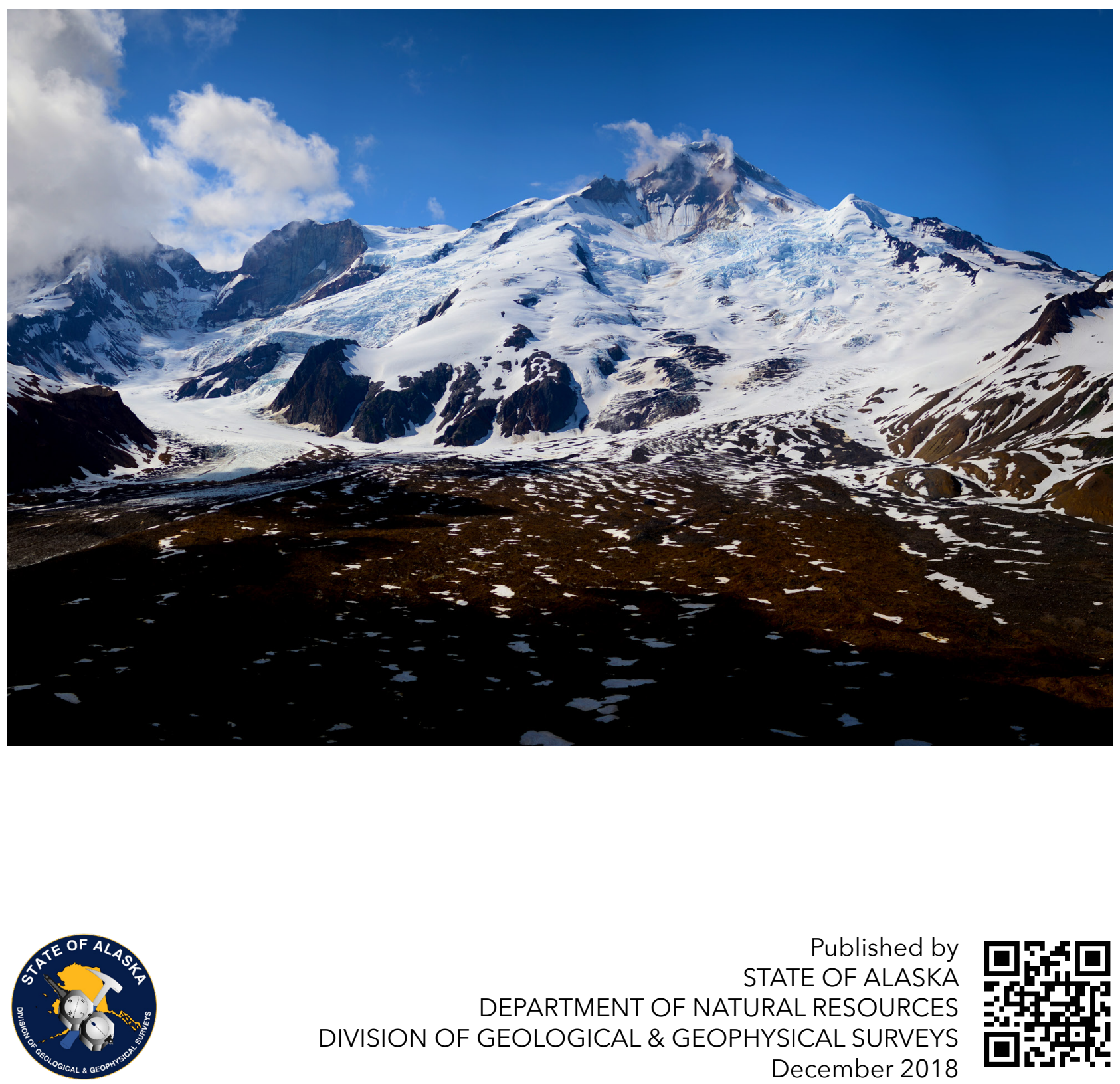

December 2018 
Cover. Steaming fumaroles of the active Iliamna Volcano situated in the hanging-wall of the Bruin Bay fault system (BBFS). The highest fracture intensities in the study area correlate with proximity to structures associated with the BBFS. 


\title{
FRACTURE INTENSITY OF THE MESOZOIC SEDIMENTARY
} FOREARC STRATA OF LOWER COOK INLET, ALASKA

\author{
J.L. Rosenthal, P.M. Betka, R.J. Gillis, and E.S. Nadin
}

Report of Investigation 2018-4

State of Alaska

Department of Natural Resources

Division of Geological \& Geophysical Surveys 
STATE OF ALASKA

Michael J. Dunleavy, Governor

DEPARTMENT OF NATURAL RESOURCES

Corri A. Feige, Commissioner

DIVISION OF GEOLOGICAL \& GEOPHYSICAL SURVEYS

Steve Masterman, State Geologist and Director

Publications produced by the Division of Geological \& Geophysical Surveys (DGGS) are available for free download from the DGGS website (dggs.alaska.gov). Publications on hard-copy or digital media can be examined or purchased in the Fairbanks office:

Alaska Division of Geological \& Geophysical Surveys 3354 College Rd., Fairbanks, Alaska 99709-3707

Phone: (907) 451-5010 Fax (907) 451-5050

dggspubs@alaska.gov|dggs.alaska.gov

DGGS publications are also available at:

Alaska State Library,

Historical Collections \& Talking Book Center

395 Whittier Street

Juneau, Alaska 99811

Alaska Resource Library and Information Services (ARLIS)

3150 C Street, Suite 100

Anchorage, Alaska 99503

Suggested citation:

Rosenthal, J.L., Betka, P.M., Gillis, R.J., and Nadin, E.S., 2018, Fracture intensity

of the Mesozoic sedimentary forearc strata of Lower Cook Inlet, Alaska:

Alaska Division of Geological \& Geophysical Surveys Report of Investigation 2018-4, 38 p. http://doi.org/10.14509/30063
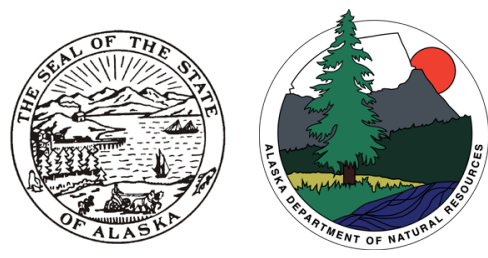



\section{Contents}

Abstract .

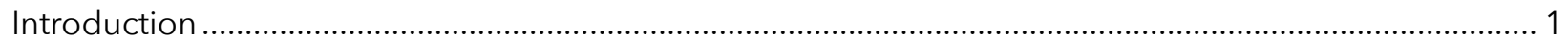

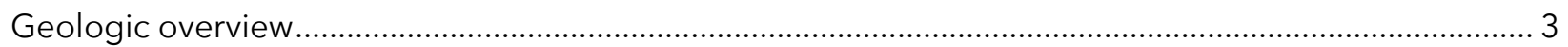

Iniskin Peninsula and southeastern Lake Clark National Park ............................................................. 4

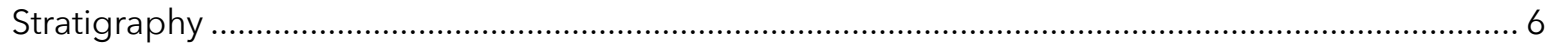

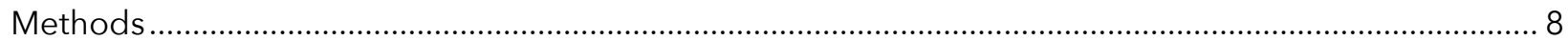

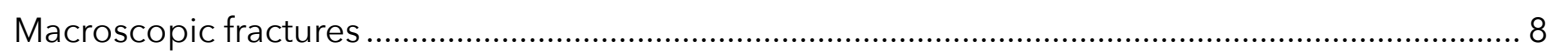

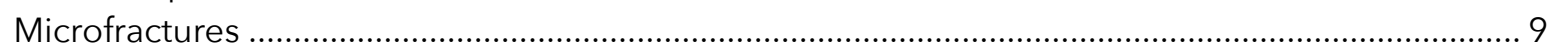

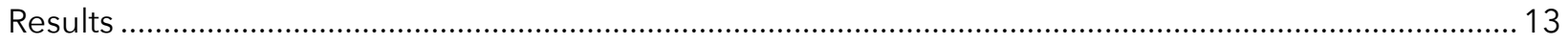

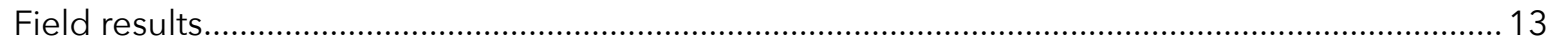

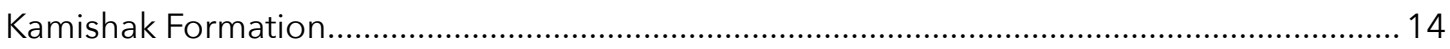

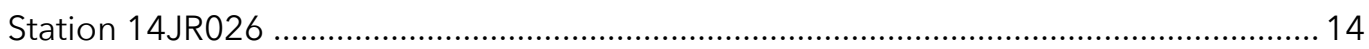

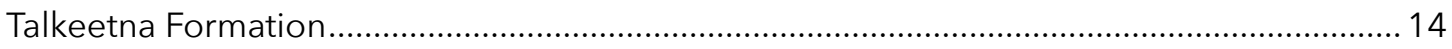

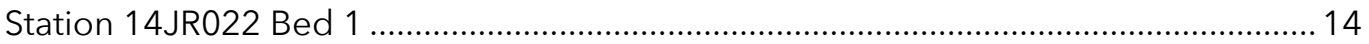

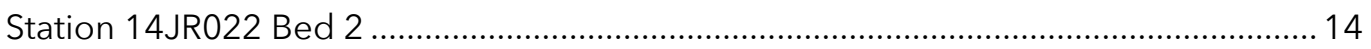

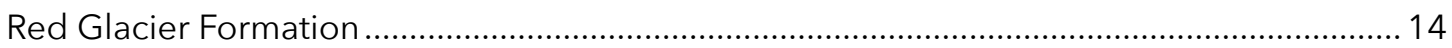

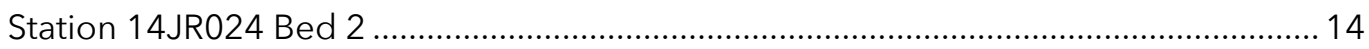

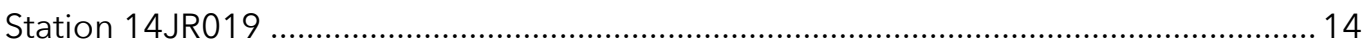

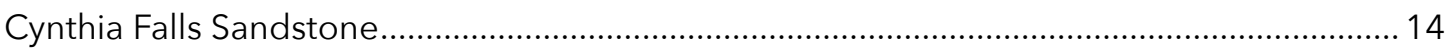

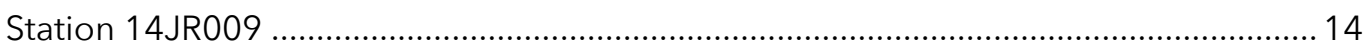

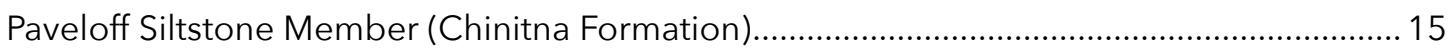

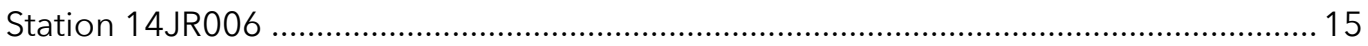

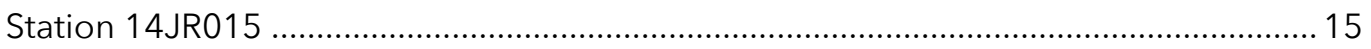

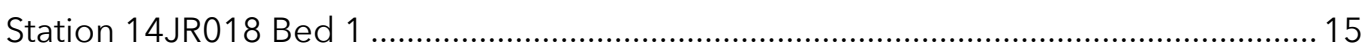

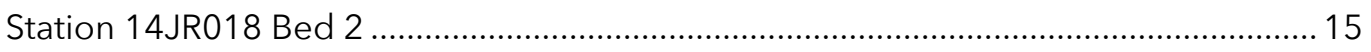

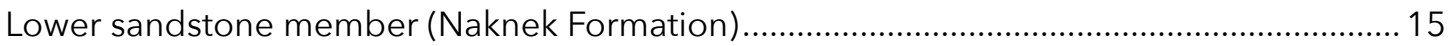

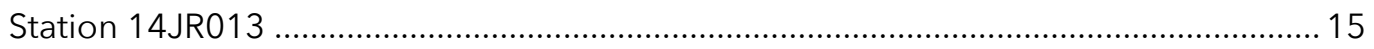

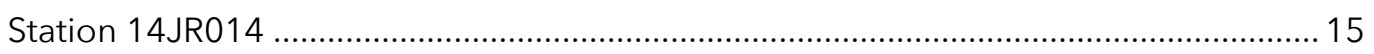

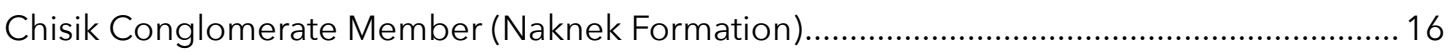

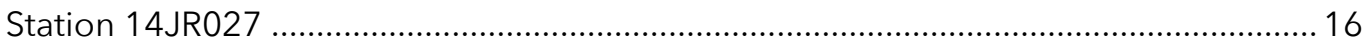

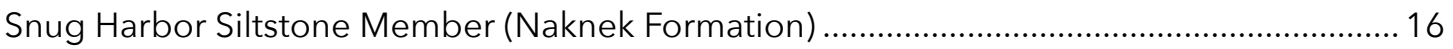

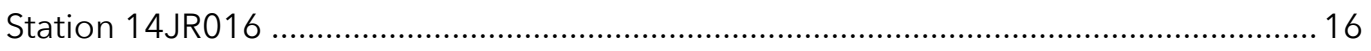

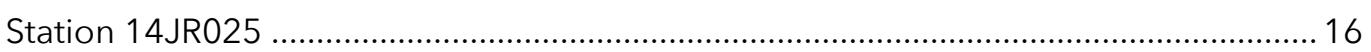

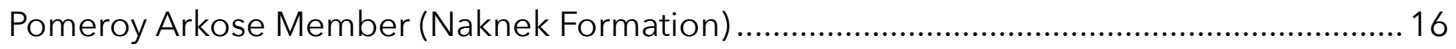

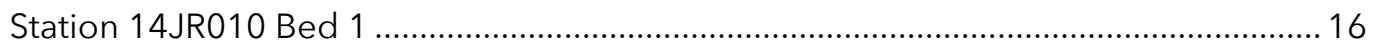

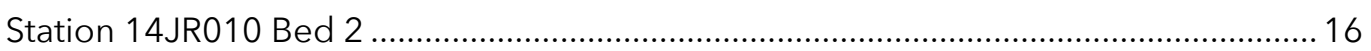

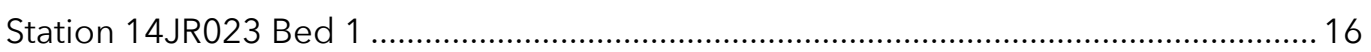

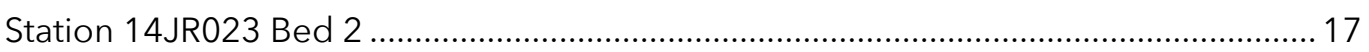

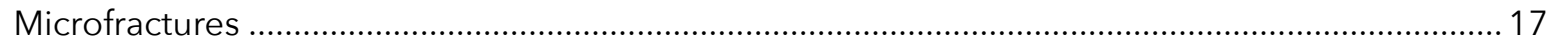

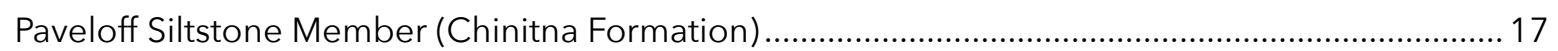

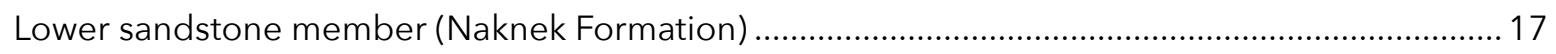

Pomeroy Arkose Member of the Naknek Formation ........................................................................ 17 
Analysis of results

Testing for correlation between fracture intensity (greater than or

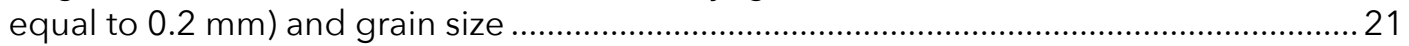

Testing for correlation between fracture intensity, stratigraphic unit, and fracture set .........28

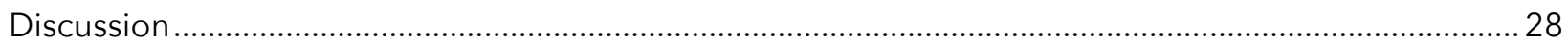

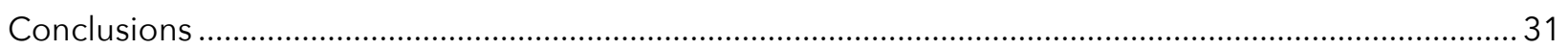

Future work

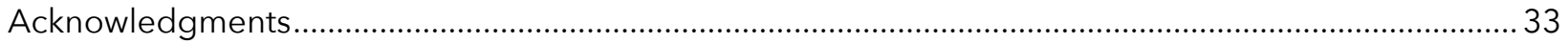

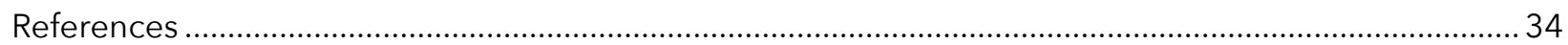

\section{Figures}

Figure 1. Outline of the study area on the simplified tectonic map of southern Alaska .......................... 3

Figure 2. Simplified stratigraphic column of the lower Cook Inlet stratigraphic thicknesses ..................... 5

Figure 3. Simplified geologic map of the study area with stations where fracture intensity

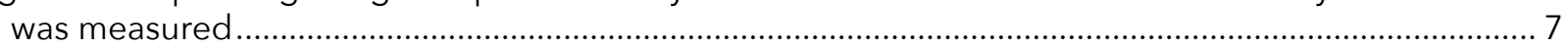

Figure 4. Rose diagram of fracture sets identified at all field localities.................................................... 8

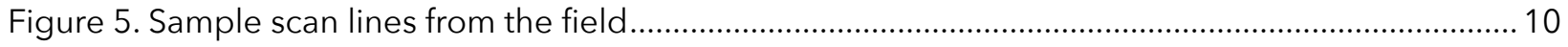

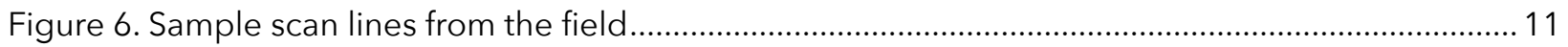

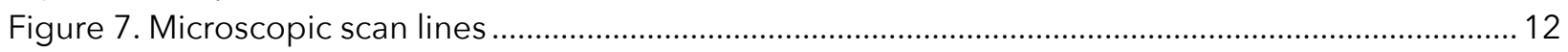

Figure 8. Cumulative frequency diagrams for fracture sets measured at each station............................ 18

Figure 9. Cumulative frequency diagrams for microscopic and macroscopic fractures for

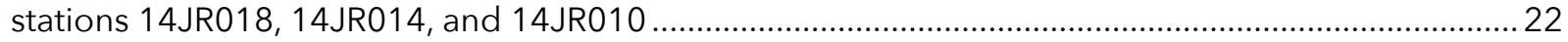

Figure 10. Plots showing fracture intensity $(F \geq 0.2 \mathrm{~mm})$ versus grain size ............................................23

Figure 11. Histograms of fracture intensity and power-law exponent versus stratigraphic unit ..............24

Figure 12. Histograms of fracture intensity, slope (power-law exponent), coefficient, annotated with values of mean, standard deviation, and mode .......................................................29

Figure 13. Box plots for fracture intensities for the four fracture sets ..........................................................30

\section{Tables}

Table 1. Station locations, fracture orientations at each station, number of apertures

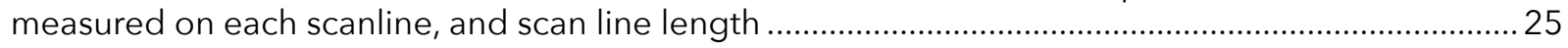

Table 2. Power law coefficients, power law exponents, and fracture intensity $(F \geq 0.2 \mathrm{~mm})$...................26

Table 3. Extension (aperture width sum), fracture strain, type, grain size, sample, and thin sections ...... 27

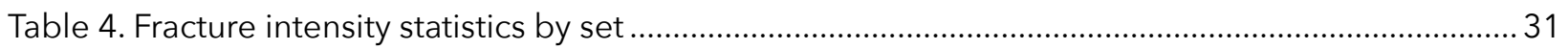





\title{
FRACTURE INTENSITY OF THE MESOZOIC SEDIMENTARY FOREARC STRATA OF LOWER COOK INLET, ALASKA
}

\author{
J.L. Rosenthal ${ }^{1,2}$, P.M. Betka ${ }^{2,3}$, R.J. Gillis², and E.S. Nadin'
}

\begin{abstract}
Fracture patterns can provide insight into the strain history and stress evolution of deformed strata. In southern Alaska's Cook Inlet forearc basin, hydrocarbon traps are typically faultcored anticlines, where fractures likely aid in the migration of hydrocarbons from Lower Jurassic marine strata into Cenozoic nonmarine deposits. Consequently, understanding the distribution and orientation of fracture sets with respect to these structures is necessary to advance the understanding of one of Alaska's largest petroleum provinces. This study aims to quantify the fracture intensity of four regional fracture sets, which are pervasive in deformed forearc basin strata of Jurassic age in the Iniskin-Tuxedni region of lower Cook Inlet, Alaska. We document how fracture intensity varies among the four regionally identified fracture sets: $310^{\circ}$ (Set A), $210^{\circ}$ (Set B), $250^{\circ}$ (Set C), and $360^{\circ}$ (Set D). Their respective intensities per meter for apertures greater than or equal to $0.2 \mathrm{~mm}$ are $6.13,4.05,4.75$, and 5.19. Grain size and stratigraphic unit are poor indicators of fracture intensity for the rock types studied in our field area. Our analysis of the fracture sets indicates that fracture intensity is most greatly influenced by proximity to large fractures and faults. We suggest that microfracture populations can serve as fair estimators of macrofracture abundance within an order of magnitude. Future microfracture work with subsurface samples could better estimate subsurface macrofracture abundance. We conclude that natural fractures could serve as migration pathways that enhance reservoir permeability in the lower Cook Inlet hydrocarbon province, and that the $310^{\circ}$ (Set A) fracture set is most favorably oriented for fracture stimulation under the current stress regime.
\end{abstract}

\section{INTRODUCTION}

Fractures control the movement of basinal fluids and serve as a secondary source of permeability in reservoir rocks where primary porosity and permeability have been lost due to diagenesis (Nelson, 1985; Solano and others, 2011). On Alaska’s Iniskin Peninsula and surrounding areas in the lower Cook Inlet forearc basin, fractures control the locations of oil shows and seeps as well as the migration of hydrocarbons (LePain and others, 2013; AOGCC, 2015; Detterman and Hartsock, 1966). Despite the rarity of forearc petroleum systems (Dickinson, 1995), economic potential could be realized in low primary porosity and primary permeability reservoirs such as the Mesozoic rocks of Cook Inlet with properly placed well bores that more effectively exploit fracture networks (for example, Engelder and others, 2009). Therefore, clarifying fracture types, orientations, and controls on fracture intensity (the number of fractures of a given size or larger per unit length) are critical to further regional petroleum exploration and production in tight rocks. Moreover, quantifying lithologic controls (such as grain size and bedding thickness) with respect to the fracture apertures and intensities of regionally mapped sets is important for the development of tight sandstones in unconventional hydrocarbon plays (Nelson, 1985; Lorenz and others, 2002; Laubach and others, 2009). Large, open fractures (greater than or equal to $0.5 \mathrm{~mm}$ aperture) are

${ }^{1}$ Department of Geosciences, University of Alaska Fairbanks, P.O. Box 755780, Fairbanks, AK 99775-5780

${ }^{2}$ Alaska Division of Geological \& Geophysical Surveys, 3354 College Road, Fairbanks, AK 99709-3707, dggspubs@alaska.gov ${ }^{3}$ Now at: Lamont-Doherty Earth Observatory of Columbia University, 61 Route 9W, P.O. Box 1000, Palisades, NY 10964-8000 
especially important for fluid migration (Laubach, 2003). Helmold and others (2013) demonstrate that Jurassic sandstones in lower Cook Inlet exhibit diminished primary porosity and permeability as a result of diagenesis, primarily from a combination of compaction due to burial at depths up to 10,000 meters and clay cementation from alteration of volcanic lithic fragments. However, several oil shows and seeps in the region are spatially associated with regional fracture networks that likely controlled the migration of hydrocarbons in the basin (Detterman and Hartsock, 1966; LePain and others, 2013; Wartes and Herriot, 2014; AOGCC, 2015).

Understanding which parameters correlate with fracture size and abundance could aid in the recovery of hydrocarbons and thus increase the economic potential of low permeability and porosity reservoirs in Jurassic strata of Cook Inlet. Examination of the Jurassic section of Cook Inlet will allow us to (1) evaluate the potential for fractured reservoirs in rocks that have poor reservoir potential due to diagenetic alteration (Helmold and others, 2013), and (2) quantify how fracture intensity (defined as the number of fractures of a specified size or larger per unit of length along a given sampling line[Marrett and others, 1999]) varies among the feldspathic and lithic sandstones and siltstones of the Mesozoic forearc sedimentary sequence. While this study focuses on fracture aperture as a proxy for fracture size (for example, Marrett and others, 1999; Ortega and others, 2006), the authors recognize the importance of length and height of fractures with regards to fluid flow and connectivity between fractures (Long and Witherspoon, 1985; Philip and others 2005; Olsen and others, 2009).

When using aperture as a proxy for fracture size, Marrett and others (1999) showed that fractures follow power-law scaling relationships when normalized for size, with macrofractures being less abundant than microfractures. Using size-normalized cumulative frequency to measure frac- ture intensity, they demonstrate that fractures in a uniform rock type follow power-law scaling relationships across five orders of magnitude of fracture size with excellent correlation (cf. Ortega and others, 2006; 2010).

It follows that by measuring microfractures in thin section, one could estimate the densities of macrofractures at reservoir scale (e.g., Hooker and others, 2014). Therefore, normalized fracture intensity is useful for quantifying the density of natural fractures in various rock types. Numerous authors have shown that power-law scaling relationships occur in various rock types, such as quartz sandstones and limestones (Ortega and others, 2010; Hooker and others, 2009; Gomez and Laubach, 2006; Hooker and others, 2014). We provide some of the first size-normalized fracture intensity data for arkosic and lithic arenites, and the first data of its kind for Cook Inlet basin. It should be noted that some lithologies lack microfractures (Anders and others, 2014), for example, Laubach and others (2016), report that microfractures appear to be less prevalent in feldspathic sandstones. This may inherently limit universal scaling relationships between microfractures and macrofractures in all situations, and thus, microfractures may only be a good proxy for fracture intensity in certain rock types.

Quantifying macrofractures (apertures greater than equal to $1 \mathrm{~mm}$ ) in the subsurface has proven difficult because vertical wells generally do not intersect many fractures (Narr, 1991), and large fractures are commonly open, making complete recovery of the fracture in core challenging (Laubach, 2003). Additionally, large fractures control the migration of basinal fluids, making their characterization critical for understanding fluid flow in reservoirs (Laubach, 1997, 2003). Because macrofracture sampling in the subsurface is difficult, abundant microfracture populations (fracture aperture $<1 \mathrm{~mm}$ ) have been used to provide estimates of macrofracture orientations, abundance, and size (Laubach, 1997; Marrett and others, 1999; Ortega and Marrett, 2000; Ortega and others, 2006; Hooker and others, 2009, 2014). 
In this study, we quantify the fracture intensity of four regional fracture sets hosted in deformed forearc basin strata of Jurassic age in the IniskinTuxedni region of lower Cook Inlet, Alaska (Rosenthal and others, 2017). Our results document the range of fracture intensities in the four sets, whose trends are $310^{\circ}$ (Set A), $210^{\circ}$ (Set B), $250^{\circ}$ (Set C), and $360^{\circ}$ (Set D) (Rosenthal and others, 2017). We document how fracture intensity varies by stratigraphic unit and with grain size. We also test the feasibility of using microfracture intensity determined in thin sections as a proxy for estimating macrofracture intensity in outcrop by comparing results from both macrofracture and microfracture scan lines from the same location and lithology. Our results are discussed in the context of exploiting natural fractures as fluid migration pathways that could enhance permeability in lower Cook Inlet hydrocarbon reservoirs, and serve as hydrocarbon migration pathways in both the lower and upper Cook Inlet petroleum system.

\section{GEOLOGIC OVERVIEW}

The Cook Inlet basin is a northeast-trending collisional forearc basin in southern Alaska (Nokleberg and others, 1994; Plafker and others, 1994). The basin is bound by the Jurassic Talkeetna Arc (a volcanic island arc sutured to the southern Alaska margin; Peninsular terrane of fig. 1) and modern Aleutian Arc to the northwest, and the Border Ranges fault to the southeast (fig. 1). The Border Ranges fault separates Cook Inlet basin

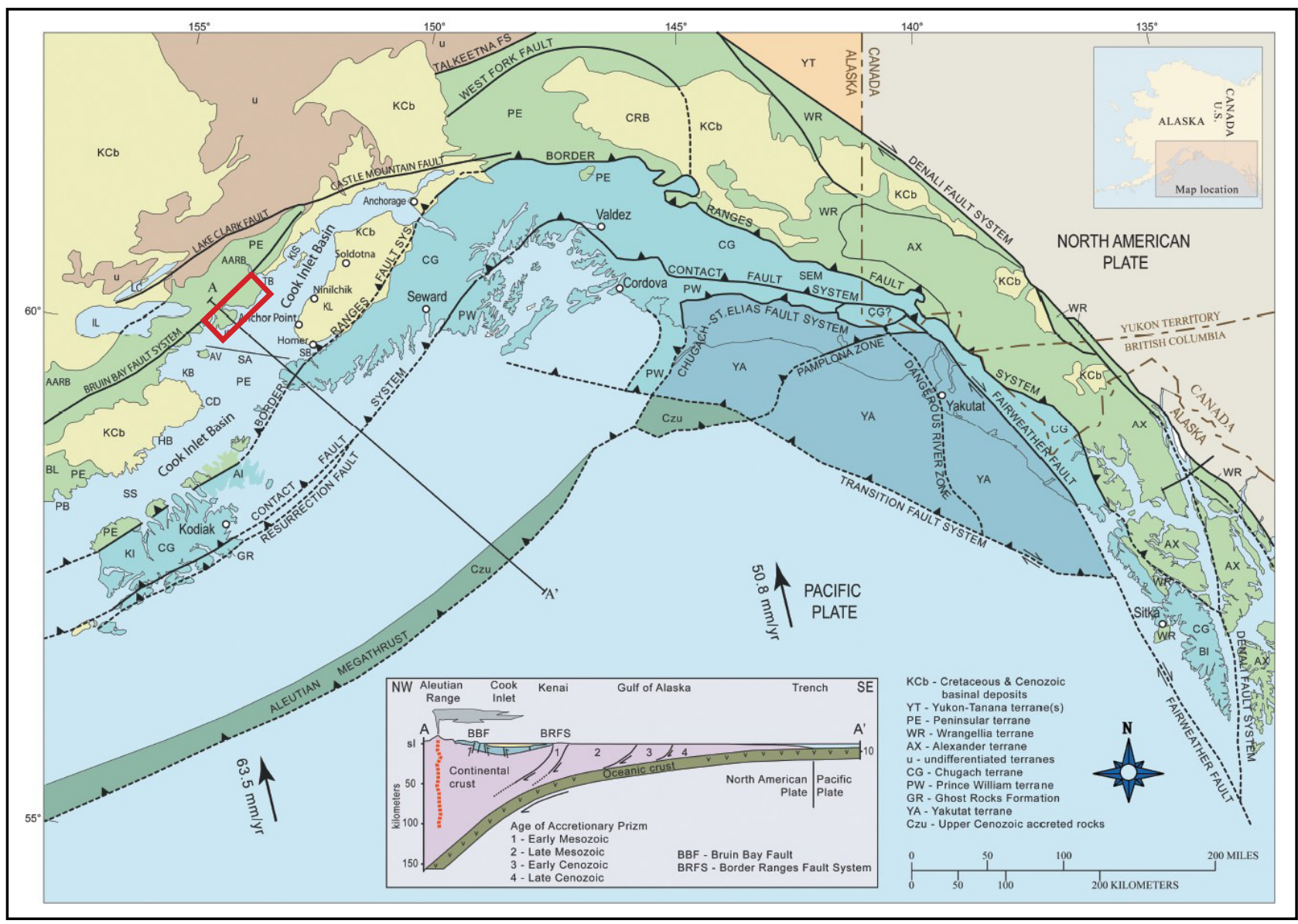

Figure 1. Outline of the study area (solid red line) on the simplified tectonic map of southern Alaska (modified from Winkler [2000] in LePain and others, 2013). Inset cross-section modified from Fisher and Magoon (1978). Key to abbreviations not defined on map: $\mathrm{AARB}=$ Aleutian-Alaska Range Batholith; $\mathrm{Al}=$ Afognak Island; $\mathrm{AV}=\mathrm{Augustine}$ Volcano; $\mathrm{BI}=\mathrm{Baranof}$ Island; $\mathrm{BL}=$ Becharof Lake; $\mathrm{CD}=$ Cape Douglas; $\mathrm{CRB}=$ Copper River basin; $\mathrm{HB}=$ Hallo Bay; $\mathrm{KB}=\mathrm{Kamishak} \mathrm{Bay;} \mathrm{KI}=\mathrm{Kodiak}$ Island; KIS = Kalgin Island; IP = Iniskin Peninsula; LC = Lake Clark; IL = Iliamna Lake; KL = Kenai Lowland; PB = Puale Bay; $\mathrm{TB}=$ Tuxedni Bay; SB = Seldovia Bay; SA = Seldovia arch; SS = Shelikof Strait; SEM = St. Elias Mountains. 
from the Mesozoic-Cenozoic accretionary prism (Chugach-Prince William terranes) and Aleutian trench (the modern subduction zone) to the southeast (fig. 1). These elements record Mesozoic and Cenozoic subduction and terrane accretion on the southern Alaska margin (Nokleberg and others, 1994). Roughly 18,000 m of Mesozoic through early Cenozoic sedimentary rock fill the Cook Inlet basin, recording approximately 200 million years of tectonic activity at the southern Alaska margin (Kirschner and Lyon, 1973).

The 11,000 m Mesozoic section (fig. 2; Talkeetna, Tuxedni, Chinitna, and Naknek Formations) records the construction and exhumation of an oceanic island arc. It has been proposed that the several-hundred-meter-thick layer of lower Cenozoic rocks of the West Foreland Formation (which represents a small portion of the 7,600$\mathrm{m}$-thick Cenozoic section) records the initiation of subsidence after rapid forearc basin uplift and erosion induced by the subduction of buoyant crust during the passing of the Kula-Resurrection Ridge (for example, Bradley and others, 2003; Trop and Ridgway, 1999). The mechanisms for subsidence of the forearc for the majority of Cenozoic time are poorly understood. Deformation of Cenozoic rocks in the form of transpressional anticlines in upper Cook Inlet was likely driven by late Paleogene to Neogene collision of the Yakutat terrane with the southern Alaska margin (Nokleberg and others, 1994; LePain and others, 2013), although it is possible that changes in the obliquity or rate of subduction could have contributed to the creation of these Cenozoic structures (for example, Engebretson and others, 1985; Bruhn and Haeussler, 2006).

This study focuses on the Iniskin-Tuxedni region of Cook Inlet basin (fig. 1). Outcrops in the study area expose approximately $10,670 \mathrm{~m}$ (approximately 35,000 ft) of Mesozoic sedimentary strata (fig. 2) (Detterman and Hartsock, 1966; Kirschner and Lyon, 1973). Immature arkosic, lithic, and volcaniclastic arc-derived sand- stones, siltstones, and shales comprise the Mesozoic section in the study area and reflect exhumation and denudation of the Mesozoic arc to the northwest of the basin (for example, Plafker and others, 1989; Nokleberg and others, 1994; Trop and Ridgway, 2007).

Mesozoic clastic sedimentary rocks in this northeast-trending basin record forearc subsidence and sedimentation at a convergent margin for most of Mesozoic time and include the oil source rocks for Cenozoic reservoirs of the petroliferous upper Cook Inlet petroleum system (Kirschner and Lyon, 1973; Nokleberg and others, 1994; Trop and Ridgway, 2007; Magoon, 1994; Lillis and Stanley, 2011).

\section{Iniskin Peninsula and southeastern Lake Clark National Park}

The Iniskin Peninsula and Lake Clark National Park, in the lower Cook Inlet, contain Early Jurassic to latest Jurassic strata deformed into an anticline-syncline pair (Fitz Creek anticline and Tonnie syncline) bounded on the northwestern side by the northeast-striking, westward-dipping Bruin Bay fault system (BBFS) (Detterman and Hartsock, 1966). Conventional reservoir potential in these rocks has been substantially reduced through compaction and clay cementation (Helmold and others, 2013). Often times laumontite, chlorite, and smectite cements have severely reduced primary porosities (Helmold and others, 2013). However, these rocks are pervasively fractured (Rosenthal and others, 2017), and oil seeps that occur along faults and fractures (Detterman and Hartsock, 1966; Wartes and Herriot, 2014; 2015; Gillis, 2016; Herriot and Wartes; 2017) were first drilled on the Iniskin Peninsula from 1900-1906. The last well drilled on the Iniskin Peninsula was in 1959 and economic production was never realized (Blasko, 1976). One well offshore (Trading Bay Unit well M-28 in McArthur River field) has successfully exploited a fractured Jurassic reservoir in upper Cook Inlet. This fractured Jurassic reservoir (likely volcaniclastic or volcanic rocks 


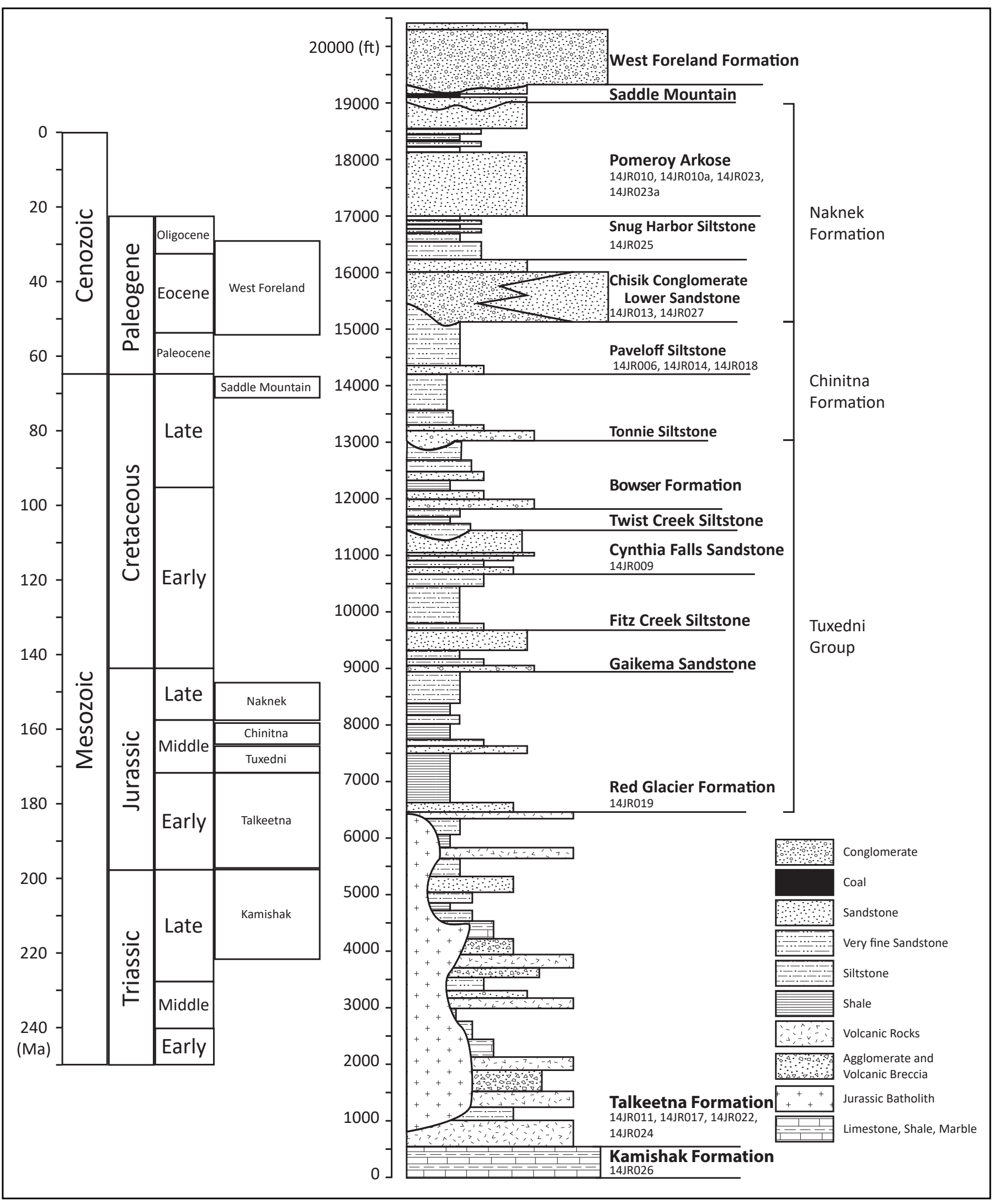

Figure 2. Simplified stratigraphic column of the lower Cook Inlet stratigraphic thicknesses. Formations and other units are drawn with typical lithologic packages and stratigraphic stacking patterns after Detterman and Hartsock (1966) and LePain and others (2013). Numbers beneath unit names represent station numbers for sites visited in each stratigraphic unit in the field. 
of the Talkeetna Formation based on borehole geophysics) has produced 180,000 barrels of oil (LePain and others, 2013, and references therein). Understanding complex fracture orientation relationships can allow for better placement of well bores that can more effectively exploit fracture networks (for example, Engelder and others, 2009), and could therefore bring economic potential to these low-porosity reservoirs.

Detterman and Hartsock (1966) compiled mapping carried out in the 1940s and 1950s on the western margins of the Iniskin-Tuxedni region and laid the framework for modern structural interpretations in the area (fig. 3). They ascribed multiple phases of regional deformation to the westward-dipping BBFS and associated folds. They interpreted $20 \mathrm{~km}$ of sinistral slip, with up to $3,000 \mathrm{~m}$ of reverse stratigraphic separation on the BBFS. Additionally, they mapped two principal joint sets, one striking $305^{\circ}$ and the other striking roughly orthogonal at $225^{\circ}$, and associated these fractures with faults in the region.

Using sedimentological constraints, others have proposed that active arc uplift and slip on the Bruin Bay fault began in the Middle Jurassic (for example, Wartes and others, 2013; Trop and Ridgway, 2007). They interpret coarse-grained arkosic lithologies and tilted contacts within the Mesozoic strata adjacent to the trace of the Bruin Bay fault as resulting from Jurassic uplift and exhumation of the arc in the hanging wall of the fault.

Recent studies have identified a polyphase deformational history of the BBFS, with evidence of a dominant phase of Paleogene sinistral transpression that is overprinted by Neogene dextral slip (Gillis and others, 2011, 2013a, 2013b; Betka and Gillis, 2014a, 2014b, 2017; Betka and others, 2017). Betka and others, (2017) concluded that the dominant Paleogene phase of sinistral transpression records southeast-trending subhorizontal shortening, while the Neogene event records southwest-trending shortening and southeast-trending extension. (Betka and Gillis, 2014a, 2017; Betka and others, 2017). These authors speculate that deformation within the BBFS records early Cenozoic plate reorganization along the southern Alaskan margin, including subduction of the hypothesized Kula-Resurrection spreading ridge (Haeussler and others, 2003) and accretion of the Chugach-Prince William terrane to the southern Alaska margin (Betka and others, 2017). Rosenthal and others (2017) interpret that several prominent vein sets formed during folding and brittle deformation associated with Paleogene slip within the BBFS (fig. 4).

\section{Stratigraphy}

Composed primarily of lava flows, volcanic breccias, agglomerates, tuffs, conglomerates, sandstones, and shales, the early Jurassic Talkeetna formation represents the remains of the now extinct Talkeetna Arc (Detterman and Hartsock, 1966; Clift and others, 2005; LePain and others, 2013). These rocks are exposed in the northwestern portion of the study area and are commonly heavily deformed in the hanging wall of the Bruin Bay fault.

The Tuxedni Group (fig. 2) is composed primarily of volcanolithic shales, siltstones, sandstones, and subordinate conglomerates (Detterman and Hartsock, 1966; LePain and others, 2013). LePain and others (2011) divide group into upper and lower units that are bounded by unconformities. The deep marine Red Glacier Formation forms the base of the Tuxedni Group. It is several hundred feet-thick (approximately $100 \mathrm{~m}$ ) and locally composed of organic-rich shale that likely serves as the oil source rock to the Cook Inlet petroleum system (Magoon and Claypool, 1981; LePain and others, 2013). However, the sedimentary facies contained in the Red Glacier Formation exhibit significant lateral variability, including fossiliferous clastic lithologies locally, suggesting strong paleo-bathymetric controls on deposition (LePain and others, 2016). Included in the lower unit, and overlying the Red Glacier Formation are the Gaikema Sandstone, Fitz Creek Siltstone, 


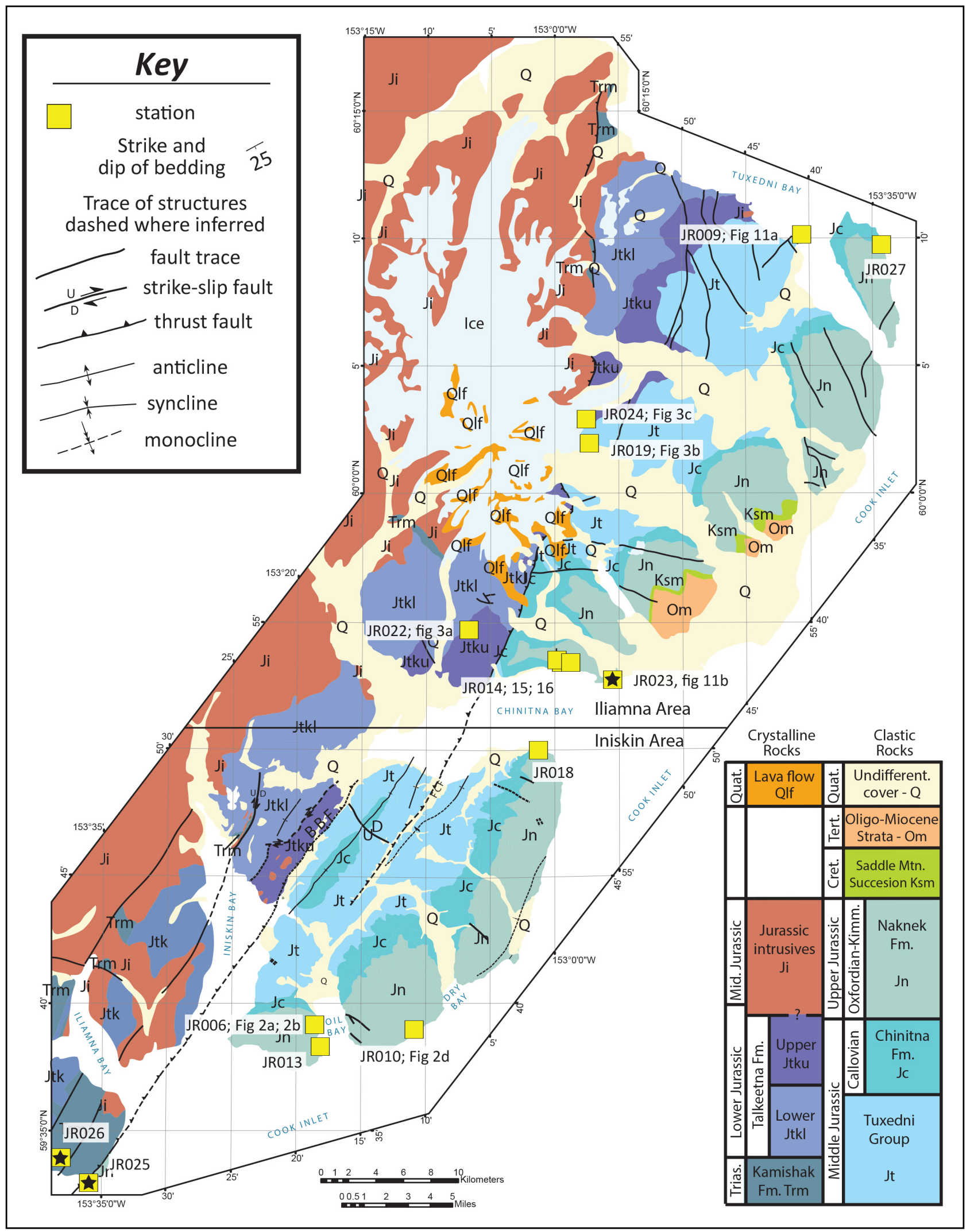

Figure 3. Simplified geologic map of the study area with stations where fracture intensity was measured (yellow squares); modified from Betka and Gillis (2015). Domains separated by thin black line that transects Chinitna Bay. Figure references and station names are shown spatially next to their corresponding yellow square. Black stars denote stations marked by black stars in figure 11 . 


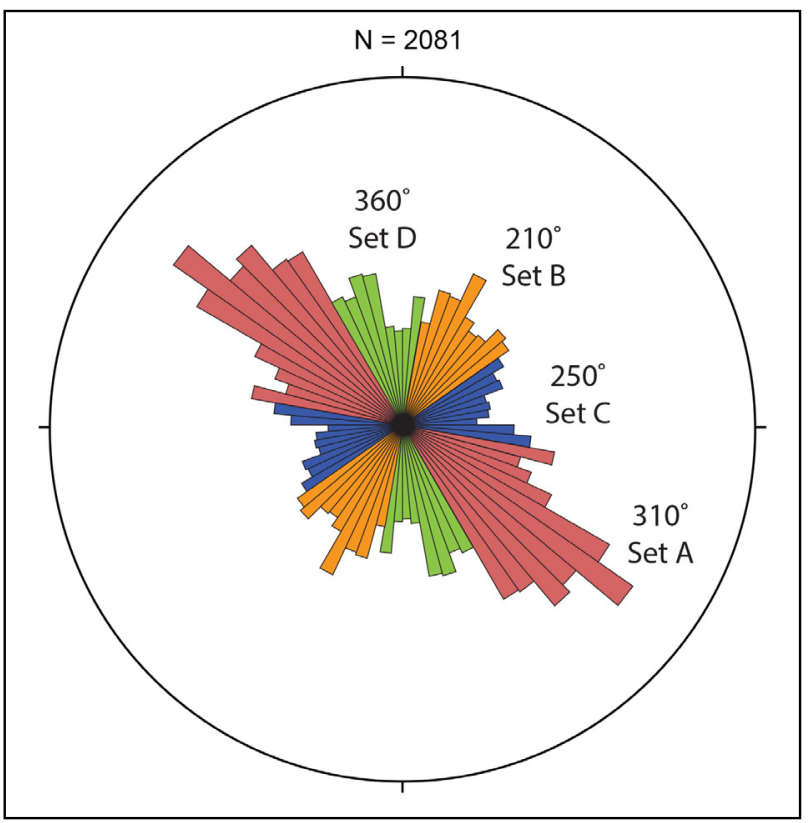

Figure 4. Rose diagram of fracture sets identified at all field localities (modified from Rosenthal and others, 2017). Mean orientation strike and dips for fracture sets $\mathrm{A}, \mathrm{B}, \mathrm{C}$, and $\mathrm{D}$ are $310^{\circ} 88^{\circ} \mathrm{NE}, 214^{\circ} 76^{\circ} \mathrm{NW}, 253^{\circ} 78^{\circ} \mathrm{N}$, and $174^{\circ} 76^{\circ} \mathrm{W}$ respectively.

and Cynthia Falls Sandstone, which represent two transgressive-regressive cycles (LePain and others, 2011, 2013). The Twist Creek Siltstone and Bowser Formation comprise the upper unit of the Tuxedni Group and are composed primarily of siltstone and fossiliferous marine sandstone, respectively (Detterman and Hartsock, 1966; LePain and others, 2013). However, the Bowser Formation unconformably overlies the lower unit of the Tuxedni Group (Cynthia Falls Sandstone) where Twist Creek Siltstone is locally absent (Detterman and Hartsock, 1966; LePain and others, 2011). Altogether, the sedimentary rocks of the Tuxedni Group record the uplift, exhumation, and erosion of the Talkeetna arc carapace during Lower to Middle Jurassic time (Detterman and Hartsock, 1966; Plafker and others, 1989; Trop and others, 2005).

The Middle Jurassic Chinitna Formation (fig. 2) is composed of two dominantly siltstone members: the Tonnie Siltstone and the Paveloff Siltstone. The Tonnie includes a locally conglomeratic basal sandstone interval up to approximately 197 feet-thick $(60 \mathrm{~m})$, and the Paveloff includes a basal sandstone approximately 33 feet-thick $(10 \mathrm{~m})$. (LePain and others, 2013). These two units unconformably overlie the top of the Tuxedni Group and are unconformably overlain by the Naknek Formation (Detterman and Hartsock, 1966). They were deposited in a predominantly deep continental shelf setting and represent deepening of the forearc basin (LePain and others, 2013).

The overlying Upper Jurassic Naknek Formation (fig. 2) is a thick unit recording the exhumation and unroofing of the Jurassic Talkeetna arc plutonic roots after the arc carapace had been largely eroded (Detterman and Hartsock, 1966; Trop and others, 2005; Wartes and others, 2013; Herriot and others, 2016). The Chisik Conglomerate is the basal member of the Naknek Formation that unconformably overlies the Chinitna Formation (Detterman and Hartsock, 1966). The unit unconformably overlies the Chinitna Formation and is composed principally of conglomerate containing dioritic and granodioritic clasts and coarse sandstone that (Detterman and Hartsock, 1966; Wartes and others, 2011). The overlying Snug Harbor Siltstone is primarily composed of thin-bedded, fossiliferous, fine- to very-fine-grained, interbedded sandstone and siltstone (Wartes and others, 2013). This unit represents a transgressive succession and subsidence of the forearc in Late Jurassic time (Detterman and Hartsock, 1966; Wartes and others, 2013). The top member of the Naknek Formation is the Pomeroy Arkose Member, a thick, dominantly arkosic sandstone with minor conglomerate and siltstone (Detterman and Hartsock, 1966; Wartes and others, 2013; Wartes and Herriott, 2014). This unit likely represents basin-floor and slope deposits (LePain and others, 2013; Wartes and others, 2013).

\section{METHODS}

\section{Macroscopic fractures}

This study employs the size-normalized fracture intensity (number of fractures of a given size 
or larger per unit length) measurement scheme of Ortega and others (2006). This method is a scale-independent approach to quantifying fracture aperture distribution because it normalizes the cumulative number of fractures by the length of observation.

To quantify fracture intensity, fracture sets of unique orientation were identified within several stratigraphic units in the study area. Scan lines (one-dimensional observation lines set with a string) were fixed perpendicular to each observed fracture set and we measured the position and aperture (width) of every cement-filled fracture that intersected each scan line. A tape measure and logarithmically graduated fracture aperture comparator (figs. 5 and 6; Ortega and others, 2006) were used to measure fracture spacings and apertures, respectively. We measured fracture apertures along 31 scan lines at 20 localities (fig. 3) from nine stratigraphic units (fig. 2). Only cement-filled fracture apertures were measured because the fracture fill preserves the opening aperture size, making the aperture less likely to be widened by post-fracturing processes such as erosion. Unfilled fractures were not sampled. Weather, tides, and exposure size and quality dictated the number of fracture sets sampled at each outcrop. Multiple fracture sets were measured where possible on well-exposed bedding surface pavement outcrops with significant lateral extent and fracture fill. The 31 scan lines measured in the field area range from 1.84 to $35.48 \mathrm{~m}$ in length and averaged $9.68 \mathrm{~m}$ long.

The cumulative number of fractures in each interval of measure (gradations on the comparator) were counted and normalized by the length of the scan line to determine the cumulative frequency per meter. Cumulative frequency versus aperture size distributions form power-law scaling relationships (for example, Marrett and others, 1999; Ortega and others, 2006; 2010; Hooker and others, 2009; 2014). The coefficient and exponent of the power-law are determined by a least-squares regression, which is plotted on a graph of cumu- lative frequency (y-axis) versus aperture ( $\mathrm{x}$-axis) in $\log -\log$ space. The coefficient of this power-law least-squares regression represents the predicted number of fractures of greater than or equal to 1 $\mathrm{mm}$ per unit length, and the exponent represents the slope of the line. The slope is dependent on the abundance and range of fracture sizes (for example, Ortega and others, 2006). Often these regressions exhibit truncation and sampling biases. Truncation bias reflects a tendency to under sample fractures near the lower limit of detection. A sampling bias reflects the absence of large fractures encountered along the scan line because these fractures are less frequent. Data affected by truncation and sampling biases plot below the regression line; in this study, data that reflect biases are excluded when calculating the least-squares regression, following the methods of Ortega and others (2006). For this study, data for regressions were truncated at fracture apertures greater than equal to $0.2 \mathrm{~mm}$, as we often saw sampling biases with our distributions with fractures greater than $0.2 \mathrm{~mm}$. We use the regression equation to compare fracture intensities from fracture sets at the 20 sampling locations (fig. 3) to determine how fracture intensity correlates with stratigraphic unit and grain size. Fracture strain was quantified by dividing the [Final Length-Initial Length] by the [Initial Length]. This measurement is the cumulative sum of all fracture apertures divided by the initial length of the scan line and gives the magnitude of extension (for example, Inigo and others, 2012). As the strain values were not the focus of this study, we performed minimal analysis of this data.

\section{Microfractures}

Fracture intensity was also determined by thin-section analysis of microfractures along microscopic scan lines in one thin section from each of three locations. Samples were collected along macroscopic scan lines so that the fracture intensity data from micro- and macroscopic scan lines could be compared. Samples were oriented parallel to the scan line (normal to the observed fracture set) and several thin sections were cut 

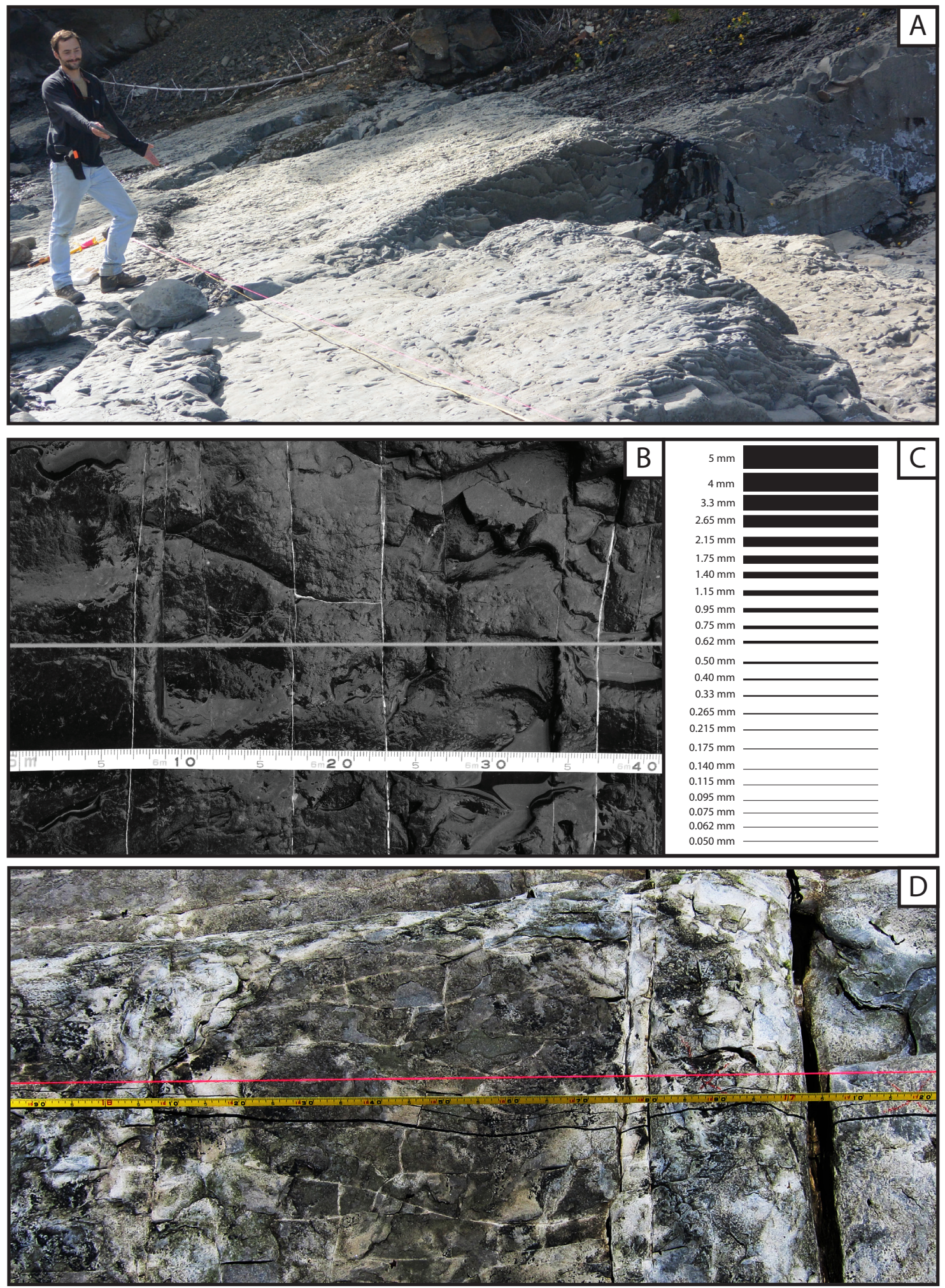

Figure 5. Sample scan lines from the field. A. Scan line at station 14JR006, strike normal to the $310^{\circ}$ Set A. Set A fractures at this location strike roughly $344^{\circ}$. B. Detailed view of scan line in A, showing several calcite-filled fractures striking normal to scan line. C. We used a logarithmically gauged fracture comparator to quickly and accurately measure fracture width while progressing along a scan line. Typically, these are microscopically calibrated; however, in the figure the comparator is not to scale. D. Scan line strikes normal to the $310^{\circ}$ Set $A$ at station 14JR010. Fractures of this set in this location strike $318^{\circ}$. Enhanced contrast and slight discoloration of the photos highlights the fractures. 

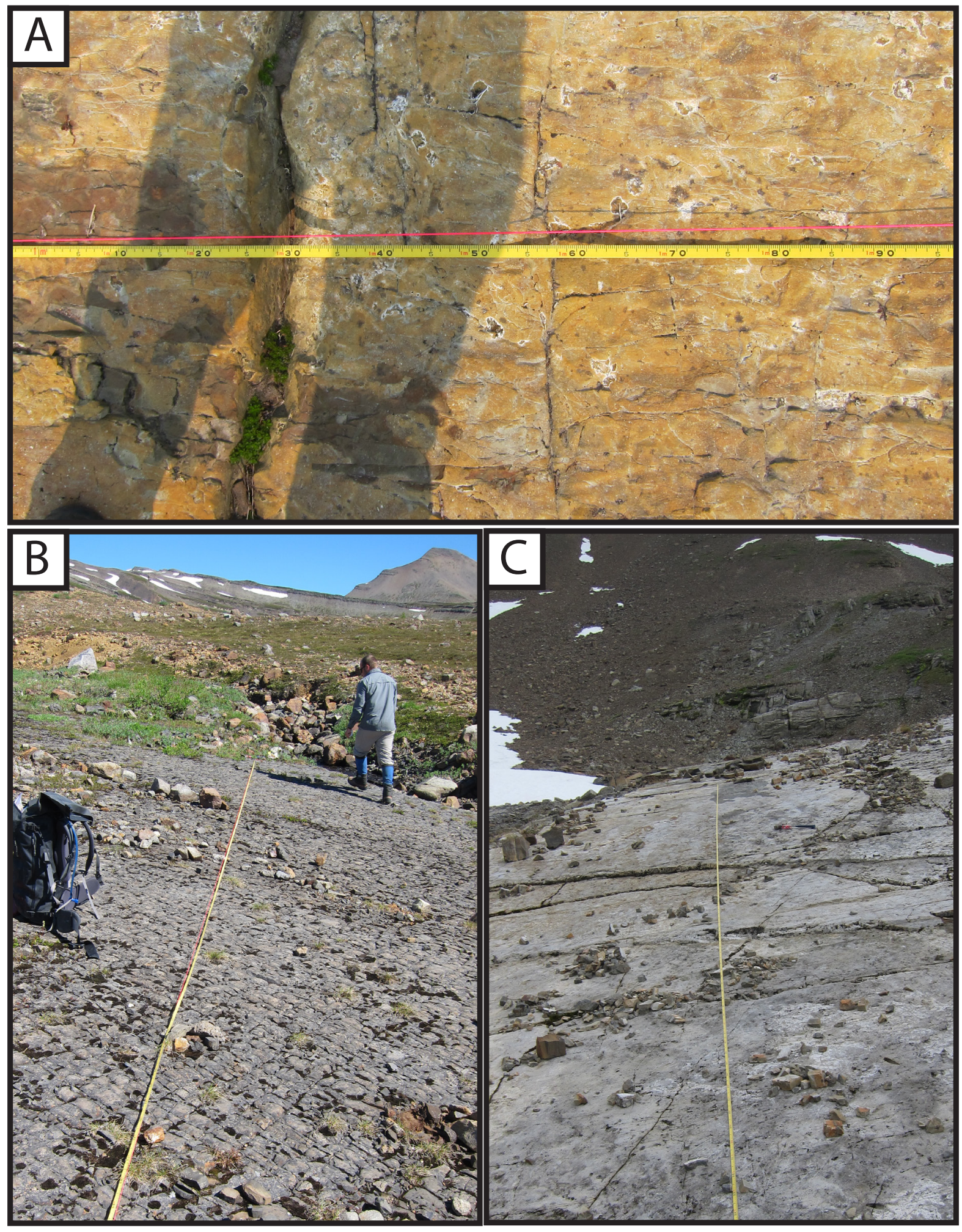

Figure 6. Sample scan lines from the field. A. Scan line at station 14JR022, strike normal to the $310^{\circ}$ Set A. Fractures of this set in this location on average strike $331^{\circ}$. B. Setting up a scan line normal to Set B at station 14 JR019. Set B fractures in this location strike $226^{\circ}$. C. Scan line at station $14 J$ R024, strike normal to the $310^{\circ}$ Set A. Fractures in this locations strike on average $302^{\circ}$. 
from one sample so that a continuous sample of the scan line was preserved (fig. 7) (refer to Gomez and Laubach [2006] for a description of the sampling methods employed in this study).

We polished and carbon coated the thin sections for use with the JEOL JXA-8530F scanning electron microscope at the University of Alaska Fairbanks Advanced Instrument Laboratory. We imaged these sections via backscattered electron microscopy, and constructed photomosaics of microfractured samples to create scan lines across each thin section. Backscattered electron microscopy images were collected using a $10 \mathrm{nA}$ beam current and $15 \mathrm{keV}$ accelerating voltage and a magnification of $500 \mathrm{x}$. Using the Thermo Scien- tific NSS microprobe imaging software, we chose an intermediate resolution of $1,024 \times 768$ pixels per image. This resolution created a quality image that could be assembled into a mosaic in a reasonable time frame. With the creation of larger grids ( 4 x 200, for instance), the software could not stitch the image successfully, so in addition to time, we were limited by software constraints. We used the software's "Grid" function, under the "Electron Imaging" menu, to collect a narrow $(1-2 \mathrm{~mm})$ grid of images along the length of the sample (approximately $30 \mathrm{~mm}$ ). This results in a grid of roughly $2 \times 150$ images. We then merged the images into a single photomosaic using the "Create Montage" function under "Batch Processing."
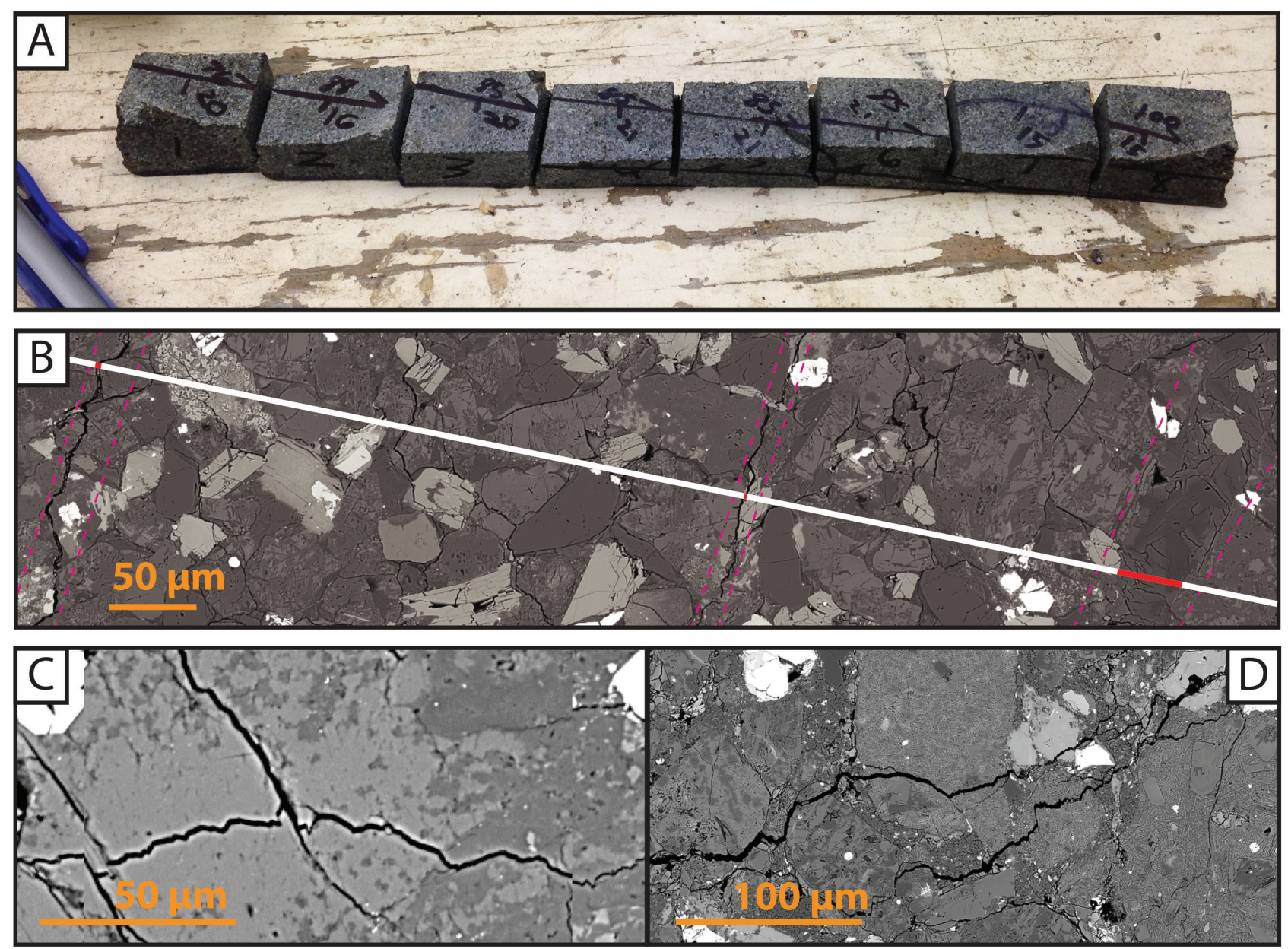

Figure 7. Microscopic scan line. A. Segmented thin section blocks to be made into a composite microscopic scan line. For more detailed explanation see figures 2 and 3 from Gomez and Laubach (2006). B. Microscopic scan line from $14 J R 014$. Scan line shown as white line, with fracture apertures highlighted in red. Filled macro fracture aperture shown at far right. C. Microscopic conjugate fractures from 14JR010 suggests that the same conjugate sets exist at both microscopic and macroscopic scales. D. Microscopic fractures from 14JR018 again suggest macroscopic features scale microscopically. 
We subsequently used Image $J^{\oplus}$ image analysis software to measure fracture apertures in the photomosaics as follows:

Set the scale of the image from a known measured length from Thermo Scientific NSS (this step assigns a length to a pixel size; i.e., 1 pixel equals 1 micron $[\mu]$ );

Draw a scan line normal to the fracture set of interest;

Draw individual lines spanning each fracture aperture along the scan line;

Use the measure function to measure each line spanning the fracture apertures;

Export the data.

Using cumulative frequency diagrams and the same methods described for macroscopic fractures, we generated log-log cumulative frequency plots of microscopic fracture apertures to determine power-law coefficients and exponents.

In the following sections, we quantify the fracture intensity by fracture set (figs. 4 and 8), and then compare the macroscopic fracture data to the microscopic data to test the validity of extrapolating power-law regressions of microfractures observed in outcrop (and potentially core) for estimating larger-scale subsurface macroscopic fracture intensity (fig. 9). The power-law equation quantifies the fracture intensity over the range of fracture sizes; the coefficients and slopes (exponents) can be used to compare fracture intensity with various lithologic parameters, such as grain size and cement percentage (for example, Ortega and others, 2010). We then perform a statistical analysis of fracture intensity versus grain size (fig. 10) and versus stratigraphic unit (fig. 11) to evaluate lithologic controls on fracture intensity.

\section{RESULTS Field results}

We defined four fracture sets for the region based on orientations, opening modes, and relative orientation between fracture sets (fig. 4) (see Rosen- thal and others, 2017). The sets are commonly perpendicular or subperpendicular to bedding and have mutual cross-cutting relationships (Rosenthal and others, 2017). Length and height were not measured, as fractures commonly extended through outcrops and therefore length and height were not quantifiable. Fractures with larger apertures consistently were longer and more continuous, which is similar to interpretations from other studies (for example, Klimczak and others, 2009).

In outcrop, the $310^{\circ}$ fracture set manifests mainly as bed-normal mode I fractures with calcite and rarer quartz and smectite cement. The $310^{\circ}$ set commonly offsets older fracture sets and infrequently preserve kinematic indicators of dextral slip. The $210^{\circ}$ set is commonly orthogonal to sub-orthogonal to the $310^{\circ}$ set, well developed, and filled with calcite or minor quartz or smectite. The $210^{\circ}$ fracture set commonly occurs with the $310^{\circ}$ fracture set, and they often cross cut one another, suggesting a common age. The $250^{\circ}$ fracture set commonly occurs as joints or veins that are variably filled with calcite or minor smectite or quartz. They are rarely well developed, are generally shorter, and typically only occur as a minor population at each outcrop. The $360^{\circ}$ fracture set is generally represented by poorly developed shear fractures or veins that are variably filled with calcite depending on outcrop preservation. These $360^{\circ}$ fractures frequently accommodate millimeter- to centimeter-scale sinistral shear, and often occur with the $310^{\circ}$ fractures that record millimeter- to centimeter-scale dextral shear. For further discussion and analysis of these four fracture sets and their genetic relationships to one another and to the tectonics of southern Alaska, see Rosenthal and others (2017).

We used the fracture groupings outlined above to quantify macrofracture intensity at 20 stations in nine stratigraphic units using 31 scan lines and created power-law regressions for all datasets. Macroscopic fracture apertures across the 31 scan lines ranged in size from $0.05 \mathrm{~mm}$ to $10 \mathrm{~mm}$. The results, organized by stratigraphic unit and presented in stratigraphic 
order, are summarized in tables 1 and 2. Grain size and rock type for each station are listed in table 2 . Fracture strain values after Inigo and others (2012) are reported in table 3.

\section{Kamishak Formation}

Station 14JR026

We measured one scan line to document the fracture intensity of the $310^{\circ}$ fracture set (Set A) at station 14JR026 (fig. 8A), which had one of the highest fracture intensities in the study area. The scan line was $3.85 \mathrm{~m}$ long and we measured 106 apertures (table 1). The mean strike of Set A at this location is $330^{\circ}$. Fracture apertures range from 0.05 to $8 \mathrm{~mm}$ wide. The fracture intensity coefficient and slope for the power-law regression at this location are 2.25 and -0.84 , respectively (table 2 ). The rock type is micritic limestone, and grain size is very-fine lower $(0.062 \mathrm{~mm})$.

\section{Talkeetna Formation}

Station 14JR022 Bed 1

We measured one scan line to document the fracture intensity of the $310^{\circ}$ fracture set (Set A) at 14JR022 Bed 1 (fig. 8B). The scan line was $6.40 \mathrm{~m}$ long and we measured 59 apertures at the outcrop (table 1). The mean strike of Set $A$ at this location is $331^{\circ}$ and fracture apertures range from 0.05 to $1.15 \mathrm{~mm}$ wide. The fracture intensity coefficient and slope for the power-law regression at this location are 0.29 and -1.19 , respectively (table 2 ). The rock type is volcaniclastic sandstone, and grain size is medium upper $(0.5 \mathrm{~mm})$.

\section{Station 14JR022 Bed 2}

We measured one scan line to document the fracture intensity of the $310^{\circ}$ fracture set (Set A) at 14JR022 Bed 2 (fig. 8C). The scan line was $6.32 \mathrm{~m}$ long and we measured 88 apertures (table 1). The mean strike for Set A at this location is $310^{\circ}$. Fracture apertures range from 0.05 to $1.40 \mathrm{~mm}$ wide. The power-law regression coefficient and slope at this location are 0.29 and -1.36 , respectively (table 2 ). The rock type sampled is volcaniclastic sandstone, and grain size is medium upper $(0.5 \mathrm{~mm})$.

\section{Red Glacier Formation}

Station 14JR024 Bed 2

We measured four scan lines in four fracture sets at station $14 \mathrm{JR} 024 \mathrm{Bed} 2$ (the $310^{\circ}$ [Set A], $210^{\circ}$ [Set B], $250^{\circ}$ [Set C], and $360^{\circ}$ [Set D] fracture sets) in the Red Glacier Formation (figs. 2 and 8D). Scan line lengths were $7.95 \mathrm{~m}$ (number of fractures measured $[\mathrm{n}]=224), 5.04 \mathrm{~m}(\mathrm{n}=167)$, $2.48 \mathrm{~m}(\mathrm{n}=112)$, and $1.90 \mathrm{~m}(\mathrm{n}=48)$ for sets $A$, $\mathrm{B}, \mathrm{C}$, and $\mathrm{D}$, respectively (table 1 ). The mean strike for each set is $325^{\circ}$ (Set A), $231^{\circ}$ (Set B), $275^{\circ}$ (Set $\mathrm{C}$ ), and $360^{\circ}$ (Set D) (table 1). Fracture apertures range from 0.05 to $2.65 \mathrm{~mm}$ wide at this station. The fracture intensity coefficients for sets $\mathrm{A}, \mathrm{B}, \mathrm{C}$, and $\mathrm{D}$ are $0.92,0.66,1.08$, and 0.39 , respectively (table 2). Set $\mathrm{C}$ had the highest coefficient by a small margin, followed by Set A, Set B, and Set D. Power-law regression slopes for sets A, B, C., and $\mathrm{D}$ are $-1.38,-1.38,-1.30$, and -1.44 , respectively. The rock type is volcaniclastic siltstone, and grain size is very-fine lower $(0.062 \mathrm{~mm})$.

\section{Station 14JR019}

We measured three scan lines to document the fracture intensity of three fracture sets (sets A, B, and C) in the Red Glacier Formation at 14JR019 (figs. 2 and 8E). Scan line lengths were $8.45 \mathrm{~m}$ (n $=107), 6.19 \mathrm{~m}(\mathrm{n}=68)$, and $6.87 \mathrm{~m}(\mathrm{n}=88)$ for sets $A, B$, and $C$, respectively (table 1 ). The mean strike for each set is $313^{\circ}$ (Set A), $226^{\circ}$ (Set B), and $275^{\circ}$ (Set C) (table 1). Fracture apertures from all three sets range from 0.05 to $2.15 \mathrm{~mm}$. The fracture intensity coefficients for sets $\mathrm{A}, \mathrm{B}$, and $\mathrm{C}$ are 0.41 , 0.11 , and 0.69 , respectively (table 2 ). Fracture set $C$ is the most intense at this location, followed by sets $\mathrm{A}$ and $\mathrm{B}$. Power-law regression slopes for sets A, B, and $C$ are $-1.21,-1.54$, and -1.12 , respectively. The rock type is siltstone, and grain size is silt to veryfine lower $(0.05 \mathrm{~mm})$.

\section{Cynthia Falls Sandstone}

Station 14JR009

We measured one scan line of the $310^{\circ}$ fracture set (Set A) at station 14JR009 (fig. 8F). The scan line was $13.50 \mathrm{~m}$ long and we measured 108 
apertures at this pavement outcrop (table 1). The mean strike for Set A at this location is $304^{\circ}$. Fracture apertures range in size from 0.75 to $1.75 \mathrm{~mm}$. The fracture intensity coefficient and slope for the power-law regression at this location are 0.28 and -1.99 , respectively (table 2 ). The rock type is siltstone, and grain size is very-fine lower $(0.062 \mathrm{~mm})$.

\section{Paveloff Siltstone \\ Member (Chinitna Formation)}

Station 14JR006

Three scan lines at station 14JR006 were used to document the fracture intensity of three fracture sets (A, B, and C) in the Paveloff Siltstone Member (figs. 2 and 8G). Scan line lengths were $14.98 \mathrm{~m}(\mathrm{n}=449), 4.75 \mathrm{~m}(\mathrm{n}=72)$, and $15.81 \mathrm{~m}$ $(\mathrm{n}=62)$ for sets $\mathrm{A}, \mathrm{B}$, and $\mathrm{C}$, respectively (table 1). The mean strike for each set is $344^{\circ}$ (Set $A$ ), $200^{\circ}$ (Set B), and $264^{\circ}$ (Set C). Fracture apertures from all three sets range from 0.05 to $10 \mathrm{~mm}$. The fracture intensity coefficients for fracture sets A, $\mathrm{B}$, and $\mathrm{C}$ are $1.21,0.36$, and 0.29 , respectively (table 2). Set $A$ is the most intense at this location, followed by Set B, and then Set C. Power-law regression slopes for sets $\mathrm{A}, \mathrm{B}$, and $\mathrm{C}$ are -1.10 , -1.36 , and -0.96 , respectively. The rock type is siltstone, and grain size is silt to very-fine lower sand $(0.062 \mathrm{~mm})$.

\section{Station 14JR015}

We measured one scan line to document the fracture intensity of the $360^{\circ}$ fracture set (Set D) at 14JR015 (fig. 8H). The scan line was $6.3 \mathrm{~m}$ long and we measured 181 apertures (table 1). The mean strike for Set $\mathrm{D}$ at this location is $365^{\circ}$. Fracture apertures range in width from 0.05 to $7 \mathrm{~mm}$. The fracture intensity coefficient and slope for the power-law regression at this location are 1.65 and -1.06 , respectively (table 2 ). The rock type is lithic sandstone, and grain size is fine-medium lower $(0.25 \mathrm{~mm})$.

\section{Station 14JR018 Bed 1}

We measured the fracture intensity of the $310^{\circ}$ fracture set (Set A) at 14JR018 Bed 1 using a single scan line (fig. 8I). The scan line was $10.04 \mathrm{~m}$ long and 71 apertures were measured at this station (table 1). The mean strike for Set $\mathrm{A}$ at this location is $325^{\circ}$. Fracture apertures range in size from 0.05 to $1.15 \mathrm{~mm}$. The fracture intensity coefficient and slope for the power-law regression at this location are 0.23 and -1.23 , respectively (table 2 ). The rock type is lithic sandstone, and grain size is medium upper to medium lower $(0.375 \mathrm{~mm})$.

\section{Station 14JR018 Bed 2}

We measured one scan line to document the fracture intensity of the $310^{\circ}$ fracture set (Set A) at 14JR018 in a finer-grained bed (fig. 8J). The scan line was $5.1 \mathrm{~m}$ long and we measured 74 apertures (table 1). The mean strike for Set A at this location is $310^{\circ}$. Fracture apertures range in width from 0.05 to $0.75 \mathrm{~mm}$. The fracture intensity coefficient and slope for the power-law regression at this location are 0.47 and -1.15 , respectively (table $2)$. The rock type is lithic sandstone, and grain size is medium upper $(0.85 \mathrm{~mm})$.

\section{Lower sandstone member (Naknek Formation)}

Station 14JR013

Using a single scan line at $14 \mathrm{JR} 013$, we documented the fracture intensity of the $360^{\circ}$ fracture set (Set D) (fig. 8K). The scan line was $6.80 \mathrm{~m}$ long and we measured 103 apertures (table 1). The average strike for Set D at this location is $360^{\circ}$. Fracture apertures range from 0.05 to $1.15 \mathrm{~mm}$. The fracture intensity coefficient and slope for the power-law regression at this location are 0.20 and -1.57 , respectively (table 2 ). The sampled outcrop is composed of lithic sandstone with a grain size of medium lower $(0.33 \mathrm{~mm})$.

\section{Station 14JR014}

We document the fracture intensity of the $210^{\circ}$ fracture set (Set B) at station 14JR014 using one scan line (fig. 8L). The scan line was 16.80 $\mathrm{m}$ long and we measured 77 apertures (table 1). The mean strike for Set B at this location is $200^{\circ}$. Fracture apertures range from 0.05 to $2.65 \mathrm{~mm}$. The fracture intensity coefficient and slope for the power-law regression at this location are 0.93 and 
-0.77 , respectively (table 2 ). The rock type is lithic sandstone, and grain size is medium upper to very coarse lower $(1 \mathrm{~mm})$.

\section{Chisik Conglomerate Member (Naknek Formation)}

Station 14JR027

We measured one scan line to document the fracture intensity of the $310^{\circ}$ fracture set (Set A) (fig. 4) at 14JR027 (fig. 8M). The scan line was $16.73 \mathrm{~m}$ long and we sampled 54 apertures along it (table 1). The mean strike for Set A at this location is $310^{\circ}$. Fracture apertures range from 0.05 to $2.65 \mathrm{~mm}$ wide. The fracture intensity coefficient and slope for the power-law regression at this location are 0.43 and -0.74 , respectively (table 2 ). The rock type is arkosic sandstone, and grain size is very coarse upper $(1.5 \mathrm{~mm})$.

\section{Snug Harbor Siltstone Member (Naknek Formation)}

Station 14JR016

Two scan lines at 14JR016 document the fracture intensity of two fracture sets $\left(310^{\circ}\right.$ [Set A] and $210^{\circ}$ [Set B]; fig. 4) in the Snug Harbor Siltstone Member (figs. 2 and $8 \mathrm{~N}$ ). Scan line lengths were $2.03 \mathrm{~m}(\mathrm{n}=208)$ and $4.88 \mathrm{~m}(\mathrm{n}=103)$ for fracture sets $A$ and $B$, respectively. The mean strike for each set is $300^{\circ}$ (Set A) and $197^{\circ}$ (Set B) (table 1). Fracture apertures from both sets range from 0.05 to $1.75 \mathrm{~mm}$. The fracture intensity coefficients for sets $\mathrm{A}$ and $\mathrm{B}$ are 0.93 and 0.62 , respectively (table 2). Set A has the highest intensity of fracture sets at this location. Power-law regression slopes for sets A and B are -2.47 and -1.16, respectively. The rock type is siltstone, and grain size is silt to very-fine lower $(0.05 \mathrm{~mm})$.

\section{Station 14JR025}

We measured one scan line to document the fracture intensity of the $310^{\circ}$ fracture set (Set A) at 14JR025 (fig. 8O) on a vertical outcrop. The scan line was $6.99 \mathrm{~m}$ long and we measured 216 apertures along the face of the outcrop (table 1). The mean strike for Set A at this location is $307^{\circ}$. Fracture apertures range from 0.05 to $10 \mathrm{~mm}$. The power-law regression fracture intensity and slope at this location are 2.96 and -0.79 , respectively (table $2)$. The rock type is very fine siltstone $(0.05 \mathrm{~mm})$.

\section{Pomeroy Arkose Member (Naknek Formation)}

Station 14JR010 Bed 1

We measured two scan lines at 14JR010 Bed 1 to document the fracture intensity of fracture sets $\mathrm{A}$ and $\mathrm{B}$ at this station in the Pomeroy Arkose Member (figs. 2 and $8 \mathrm{P}$ ); the $250^{\circ}$ set (Set C) is present but was not measured at this locality. Scan line lengths were $35.48 \mathrm{~m}(\mathrm{n}=208)$ and $19.44 \mathrm{~m}$ $(n=103)$ for sets $A$ and $B$, respectively. The mean strike for each set is $318^{\circ}$ (Set A) and $215^{\circ}$ (Set B) (table 1). Fracture apertures from both sets range from 0.05 to $2.65 \mathrm{~mm}$. The fracture intensity coefficients for fracture sets A and B are 0.33 and 0.14 , respectively (table 2 ). Set $\mathrm{A}$ has the highest intensity of fractures at this location. Power-law regression slopes for fractures sets $A$ and $B$ are -1.07 and -1.31 , respectively. The rock type is arkosic sandstone, and grain size is medium upper $(0.65 \mathrm{~mm})$.

\section{Station 14JR010 Bed 2}

In a finer-grained bed at station 14JR010 in the Pomeroy Arkose, we measured three scan lines to document the intensity of three fracture sets $\left(310^{\circ}\right.$ [Set A], $210^{\circ}$ [Set B], and $360^{\circ}$ [Set D]) (fig. 8Q). Scan line lengths were $16.60 \mathrm{~m}(\mathrm{n}=161), 1.84 \mathrm{~m}$ $(\mathrm{n}=68)$, and $3.88 \mathrm{~m}(\mathrm{n}=102)$ for fracture sets $A$, $\mathrm{B}$, and $\mathrm{D}$, respectively (table 1$)$. The mean strike for each set is $315^{\circ}$ (Set A), $220^{\circ}$ (Set B), and $350^{\circ}$ (Set D) (table 1). Fracture apertures from all three sets range from 0.05 to $1.4 \mathrm{~mm}$. The fracture intensity coefficients for sets A, B, and D are $0.59,1.08$, and 0.73 , respectively (table 2 ). Set $B$ has the highest fracture intensity in this particular bed, followed by Set $\mathrm{D}$ and then Set A. Power-law regression slopes for fracture sets A, B, and D are -1.01, -1.27, and -1.24 , respectively. The rock type is arkosic sandstone, and grain size is medium lower $(0.5 \mathrm{~mm})$.

\section{Station 14JR023 Bed 1}

One scan line was used to document the fracture intensity of fracture set $210^{\circ}$ [Set B] at $14 \mathrm{JR} 023$ 
in a coarse-grained bed (fig. 8R). The scan line was $24.36 \mathrm{~m}$ long and we measured 73 apertures (table 1). The mean strike for Set B at this location is $230^{\circ}$. Fracture apertures range from 0.05 to 7 $\mathrm{mm}$. The fracture intensity coefficient and slope for the power-law regression at this location are 0.81 and -1.18 , respectively (table 2 ). The rock type is matrix-supported conglomerate, and matrix grain size is very coarse upper $(2 \mathrm{~mm})$.

\section{Station 14JR023 Bed 2}

We measured a single scan line in a second fine-grained bed at Station 14JR023, normal to the $310^{\circ}$ fracture set (Set A) (fig. 8S). This scan line was $8.73 \mathrm{~m}$ long and we were able to measure 108 apertures along its length (table 1 ). The mean strike for Set $A$ at this location is $295^{\circ}$. Fracture apertures range from 0.05 to $10 \mathrm{~mm}$. The fracture intensity coefficient and slope for the power-law regression at this location are 2.27 and -1.07 , respectively (table 2 ). The rock type is lithic sandstone, and grain size is medium lower to fine sand $(0.2 \mathrm{~mm})$.

\section{Microfractures}

Microfractures were quantified in thin sections from the Paveloff Member of the Chinitna Formation (14JR018), and the Pomeroy (14JR010) and lower sandstone (14JR014) members of the Naknek Formation. Microfracture measurements were compared with the macrofracture data in each location (see Discussion section below). Microscopic scan lines from the three thin sections ranged from 18 to $28 \mathrm{~mm}$ long, with an average of $24 \mathrm{~mm}$ long. Fracture fill is generally absent, thus we measured unfilled fracture apertures. Microscopic fracture apertures across the three thin sections ranged in size from 0.0003 to $0.036 \mathrm{~mm}$. Macroscopic fracture apertures from the corresponding three field sites range from .05 to $2.65 \mathrm{~mm}$. Together, the fracture apertures span five orders of magnitude.

The microfractures sampled are from the $310^{\circ}$ and $210^{\circ}$ fracture sets (sets A and B). In outcrop, the $310^{\circ}$ fracture set manifests mainly as bedding-perpendicular mode I fractures with calcite and rarer quartz and smectite cement. In thin section the microfractures are primarily unfilled, with infrequent calcite and rarer quartz filled fractures (Figure 7B). Orientations and opening modes were similar to macrofracture populations. Conjugate geometries between fractures of the $310^{\circ}$ and $360^{\circ}$ fracture sets are present but not common in thin section (Figure $7 \mathrm{C}$ ). In outcrop the $210^{\circ}$ set is commonly well developed, and preserves calcite or minor quartz veins. In thin section, microfractures of this set are primarily unfilled, although quartz and calcite veins are sometimes present (Figure $7 \mathrm{~d}$ ). The fractures were sub-vertical, and the orientations were similar to sampled macrofracture populations.

\section{Paveloff Siltstone Member (Chinitna Formation)}

One scan line was used to document the microscopic fracture intensity of the $310^{\circ}$ fracture set (Set A) in a thin section from 14JR018 Bed 1 (fig. 9A). The scan line was $28.0 \mathrm{~mm}$ long and we measured 74 apertures. The mean strike for Set $A$ is $295^{\circ}$ at this location. Fracture apertures range from $4.5 \times 10^{-4}$ to $4.5 \times 10^{-2} \mathrm{~mm}$. The fracture intensity coefficient and slope for the power-law regression at this location are 0.22 and -1.44 , respectively.

\section{Lower sandstone member (Naknek Formation)}

One scan line was used to document the microscopic fracture intensity of the $210^{\circ}$ fracture set (Set B) in a thin section from 14JR014 Bed 1 (fig. 9B). The scan line was $18.0 \mathrm{~mm}$ long and we measured 112 apertures. The mean strike for Set B at this location is $201^{\circ}$. Fracture apertures range from $2.5 \times 10-4$ to $8.9 \times 10-2 \mathrm{~mm}$. The fracture intensity coefficient and slope for the power-law regression at this location are 0.30 and -1.38 , respectively.

\section{Pomeroy Arkose Member of the Naknek Formation}

One scan line was used to document the microscopic fracture intensity of the $310^{\circ}$ fracture set (Set A) in a thin section from 14JR010 Bed 1 (fig. 9C). The scan line was $27.7 \mathrm{~mm}$ long and we measured 107 apertures. The mean strike for Set 

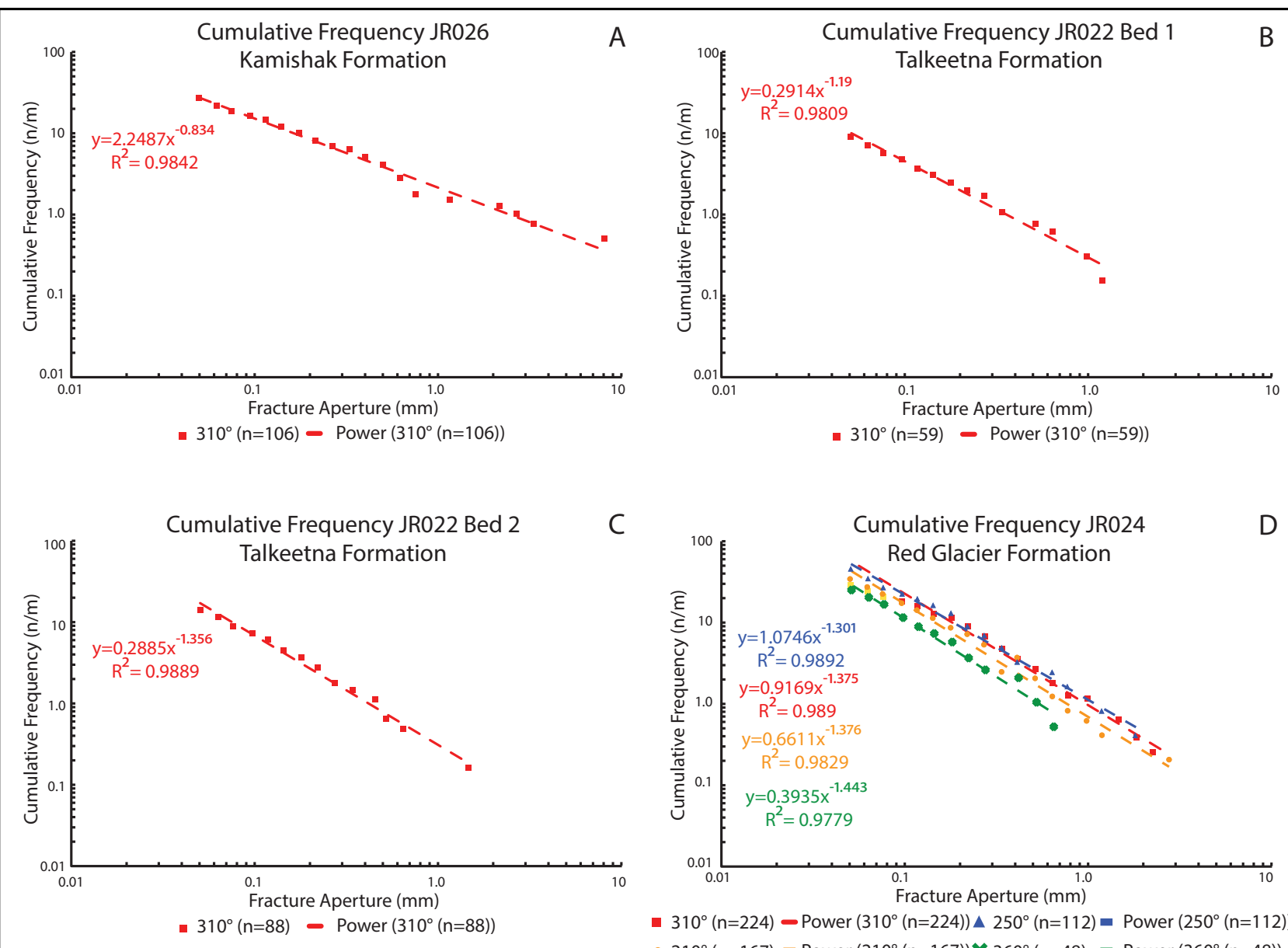

- $310^{\circ}(n=224)-\operatorname{Power}\left(310^{\circ}(n=224)\right) \Delta 250^{\circ}(n=112)$ - Power $\left(250^{\circ}(n=112)\right.$

- $210^{\circ}(n=167)=\operatorname{Power}\left(210^{\circ}(n=167)\right) \times 360^{\circ}(n=48)$ Power $\left(360^{\circ}(n=48)\right)$
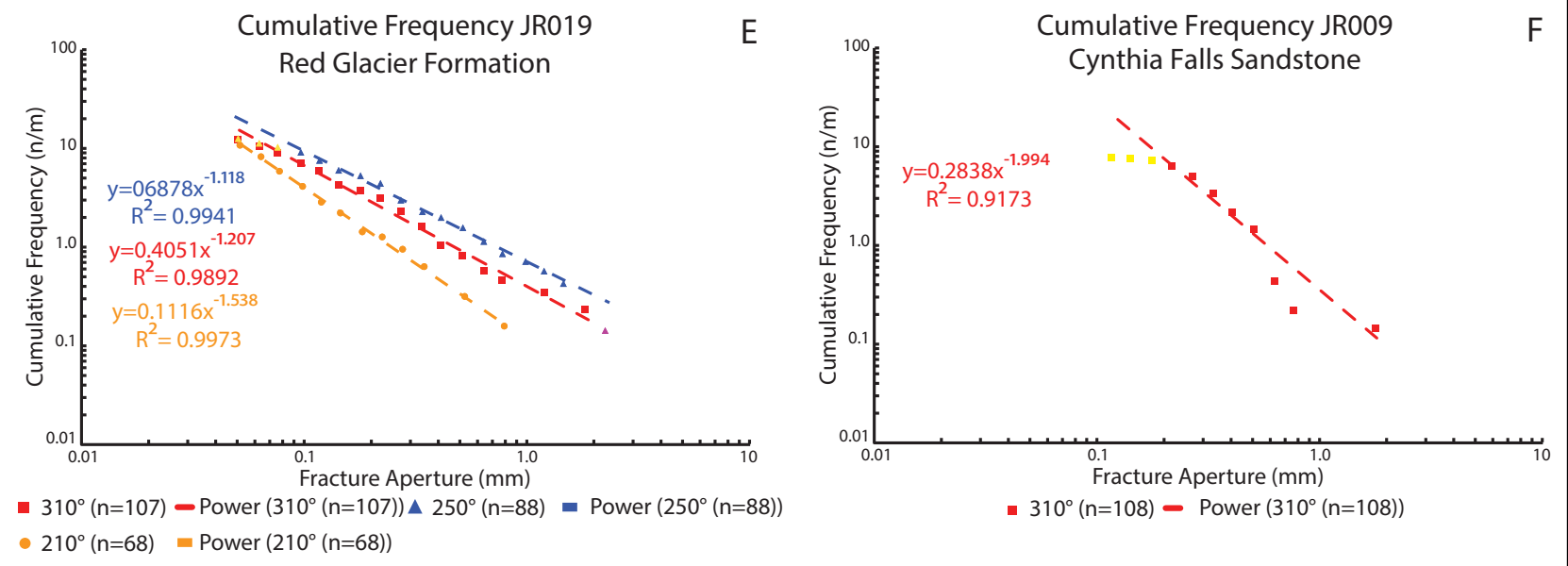

Figure 8. Cumulative frequency diagrams for fracture sets measured at each station. Plots are logarithmic on the $x$ and $y$ axes with the $x$ axis representing fracture aperture and the $y$ axis representing cumulative frequency per meter. $310^{\circ}$ Set A denoted with red; $210^{\circ}$ Set $B$ denoted with orange; $250^{\circ}$ Set $C$ denoted with blue; $360^{\circ}$ Set $\mathrm{D}$ denoted with green. Power-law regressions for each set are shown corresponding color to symbols with dashed lines. Power-law regression equation shown as red text. Station number shown in graph title. See text for discussion. 


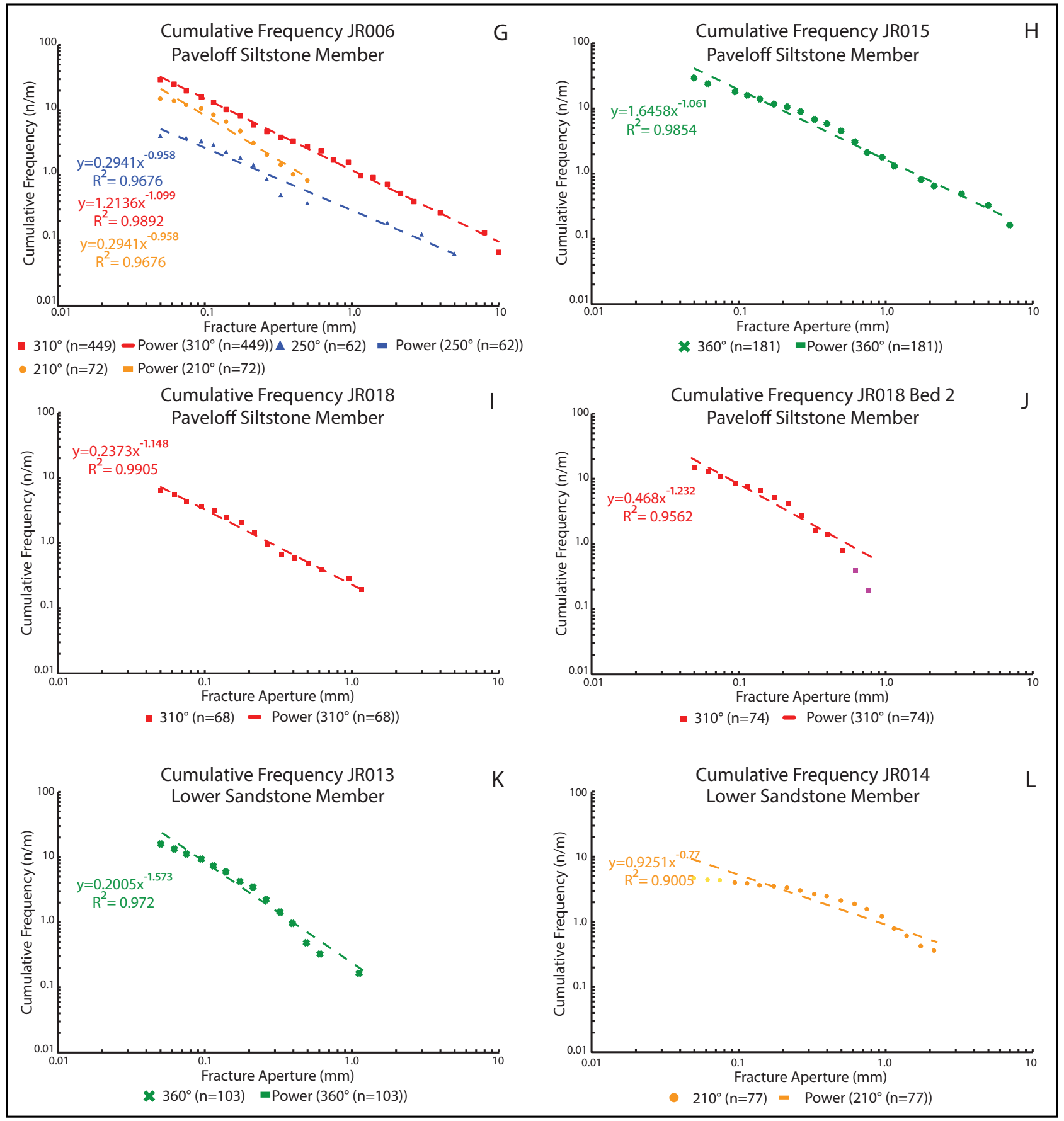

Figure 8, continued. Cumulative frequency diagrams for fracture sets measured at each station. Plots are logarithmic on the $x$ and $y$ axes with the $x$ axis representing fracture aperture and the $y$ axis representing cumulative frequency per meter. $310^{\circ}$ Set $A$ denoted with red; $210^{\circ}$ Set $B$ denoted with orange; $250^{\circ}$ Set $C$ denoted with blue; $360^{\circ}$ Set $D$ denoted with green. Power-law regressions for each set are shown corresponding color to symbols with dashed lines. Power-law regression equation shown as red text. Station number shown in graph title. See text for discussion. 


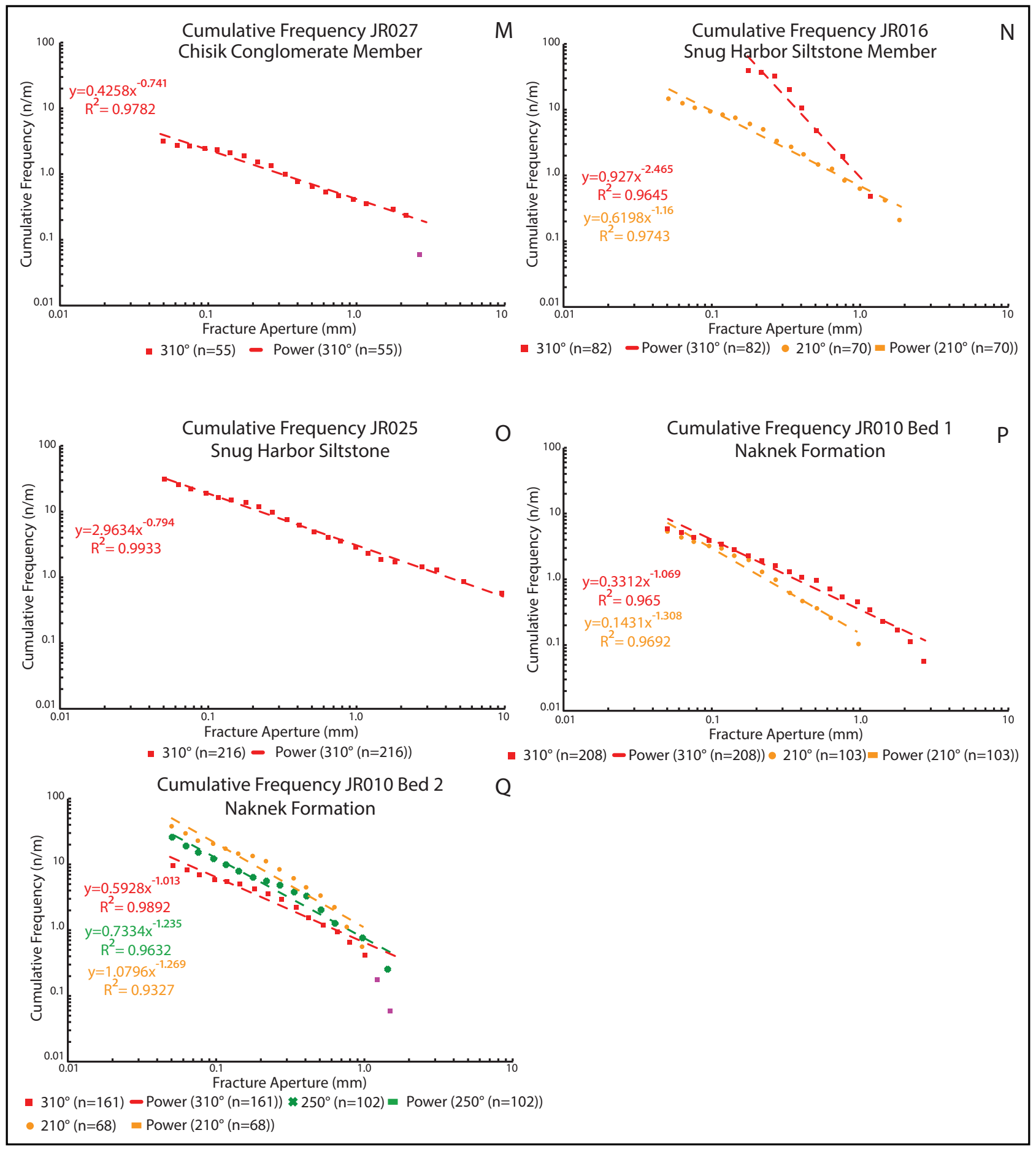

Figure 8, continued. Cumulative frequency diagrams for fracture sets measured at each station. Plots are logarithmic on the $x$ and $y$ axes with the $x$ axis representing fracture aperture and the $y$ axis representing cumulative frequency per meter. $310^{\circ}$ Set $A$ denoted with red; $210^{\circ}$ Set B denoted with orange; $250^{\circ}$ Set $C$ denoted with blue; $360^{\circ}$ Set $D$ denoted with green. Power-law regressions for each set are shown corresponding color to symbols with dashed lines. Power-law regression equation shown as red text. Station number shown in graph title. See text for discussion. 


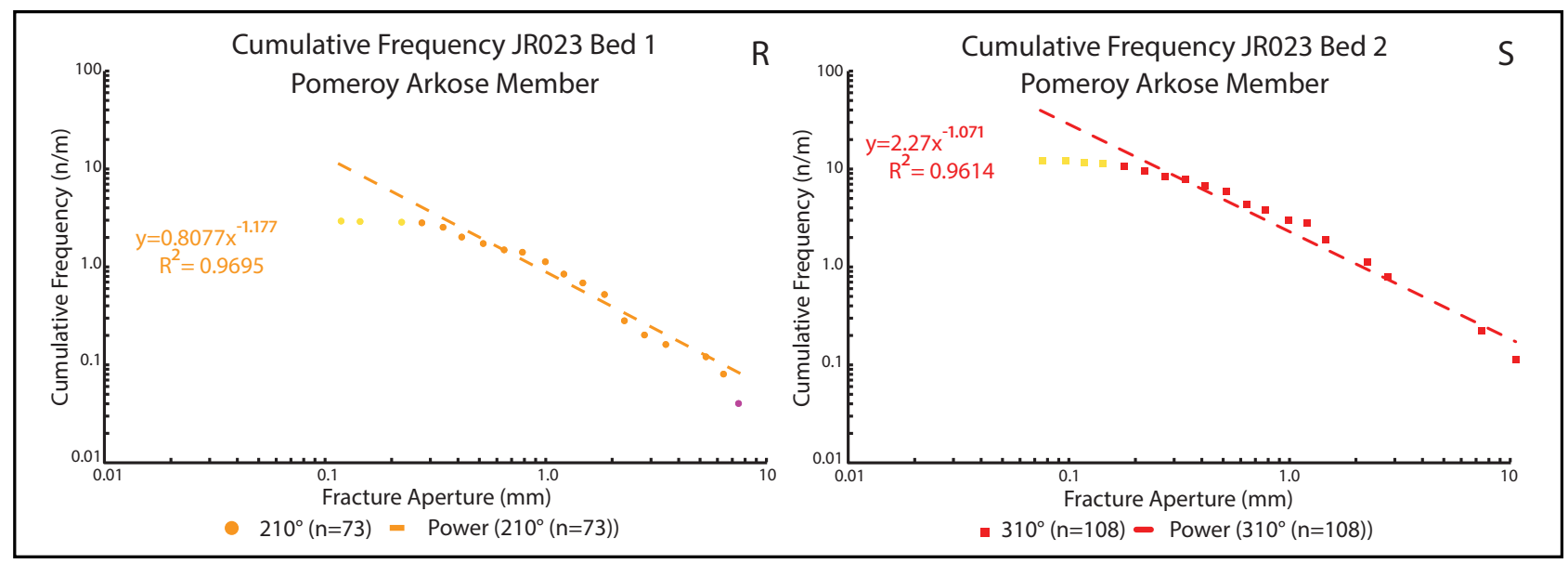

Figure 8, continued. Cumulative frequency diagrams for fracture sets measured at each station. Plots are logarithmic on the $x$ and $y$ axes with the $x$ axis representing fracture aperture and the $y$ axis representing cumulative frequency per meter. $310^{\circ}$ Set A denoted with red; $210^{\circ}$ Set B denoted with orange; $250^{\circ}$ Set C denoted with blue; $360^{\circ}$ Set D denoted with green. Power-law regressions for each set are shown corresponding color to symbols with dashed lines. Power-law regression equation shown as red text. Station number shown in graph title. See text for discussion.

$A$ at this location is $318^{\circ}$. Fracture apertures range from $5 \times 10^{-4}$ to $4 \times 10^{-3} \mathrm{~mm}$. The fracture intensity coefficient and slope for the power-law regression at this location are 0.28 and -1.30 , respectively.

\section{Analysis of results}

In this section, we statistically analyze the cumulative frequency distributions of each fracture set $[F]$ (where $F=$ the cumulative number of fractures with apertures greater than or equal to $0.2 \mathrm{~mm}$ ). The cumulative frequency distributions serve to quantify the distribution of fracture sizes measured at the outcrop. The equations that fit these cumulative frequency diagrams (in this case power law regressions) allow us to create a mathematical expression of the fracture intensity. For instance, for a fracture intensity of $0.2 \mathrm{~mm}$ or larger (or the predicted number of fractures we would expect to find per meter of $0.2 \mathrm{~mm}$ or larger) we would plug in 0.2 into the power law regression. Using this data, we test for a relationship between grain size and fracture intensity and evaluate how fracture intensity varies across different stratigraphic units in the field area. Lastly, we qualitatively evaluate four example scan lines to examine whether fractures cluster by size.

\section{Testing for correlation between fracture intensity (greater than or equal to $0.2 \mathrm{~mm}$ ) and grain size}

We plotted grain size versus fracture intensity ( $F$ greater than or equal to $0.2 \mathrm{~mm}$ ) for all four fracture sets (fig. 10) to test for a relationship between fracture intensity and grain size. The $310^{\circ}$ fracture set (Set A) shows a poor negative correlation between fracture intensity and grain size $\left(\mathrm{R}^{2}=\right.$ 0.334; fig. 10A). The three remaining fracture sets show no correlation between fracture intensity and grain size ( $\mathrm{R}^{2}$ less than 0.1 in each case). When all of the data are plotted together, there is no correlation $\left(\mathrm{R}^{2}=0.089\right.$; fig. $\left.10 \mathrm{E}\right)$. Therefore, contrary to the findings of Lianbo and Xiang-Yang (2009), we conclude that in the beds and stratigraphic units we sampled, fracture intensity is not noticeably influenced by grain size. We suggest instead that $\mathrm{F}$ is influenced more strongly by other factors in this study area, such as proximity to larger faults and/ or the progressive growth of local folds (see Betka and others, 2017; Rosenthal and others, 2017). 
Figure 9. Cumulative frequency diagrams for microscopic and macroscopic fractures for stations 14JR018, 14JR014, and 14JR010. Plots are logarithmic on the $x$ and $y$ axes with the $x$ axis representing fracture aperture and the $y$ axis representing cumulative frequency per meter. 14JR018 (A) and 14JR010

(B) show fractures from the $310^{\circ}$, and 14JR014 shows fractures from the $210^{\circ}$ set $(\mathbf{C})$. Microscopic fractures are shown with blue and macroscopic fractures are shown with red. Regression lines are color-coded to coordinate with the microscopic or macroscopic data and extrapolated to show differences in predicted and actual estimations. The black line is the regression line for the combined microscopic and macroscopic fractures.

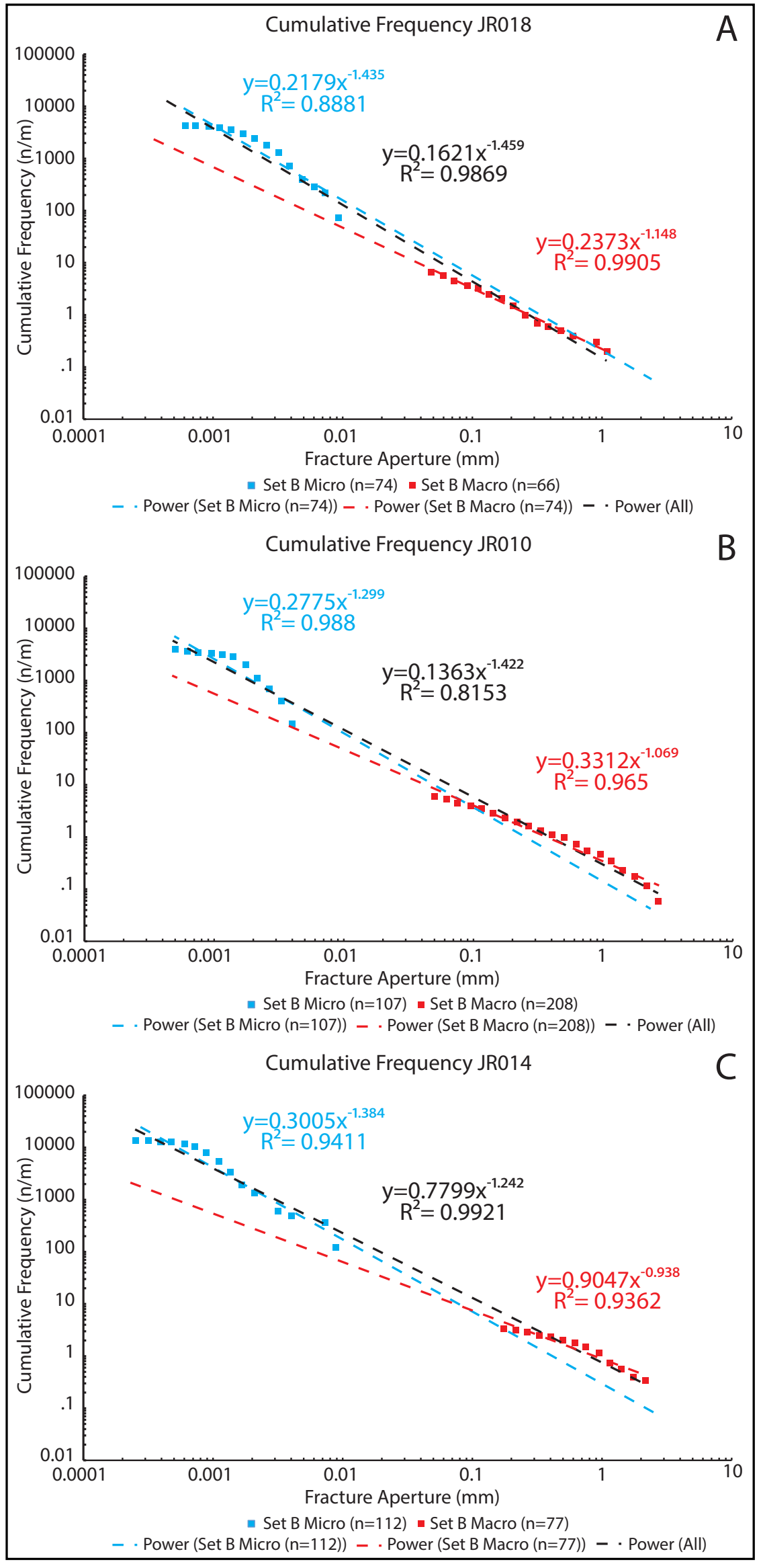




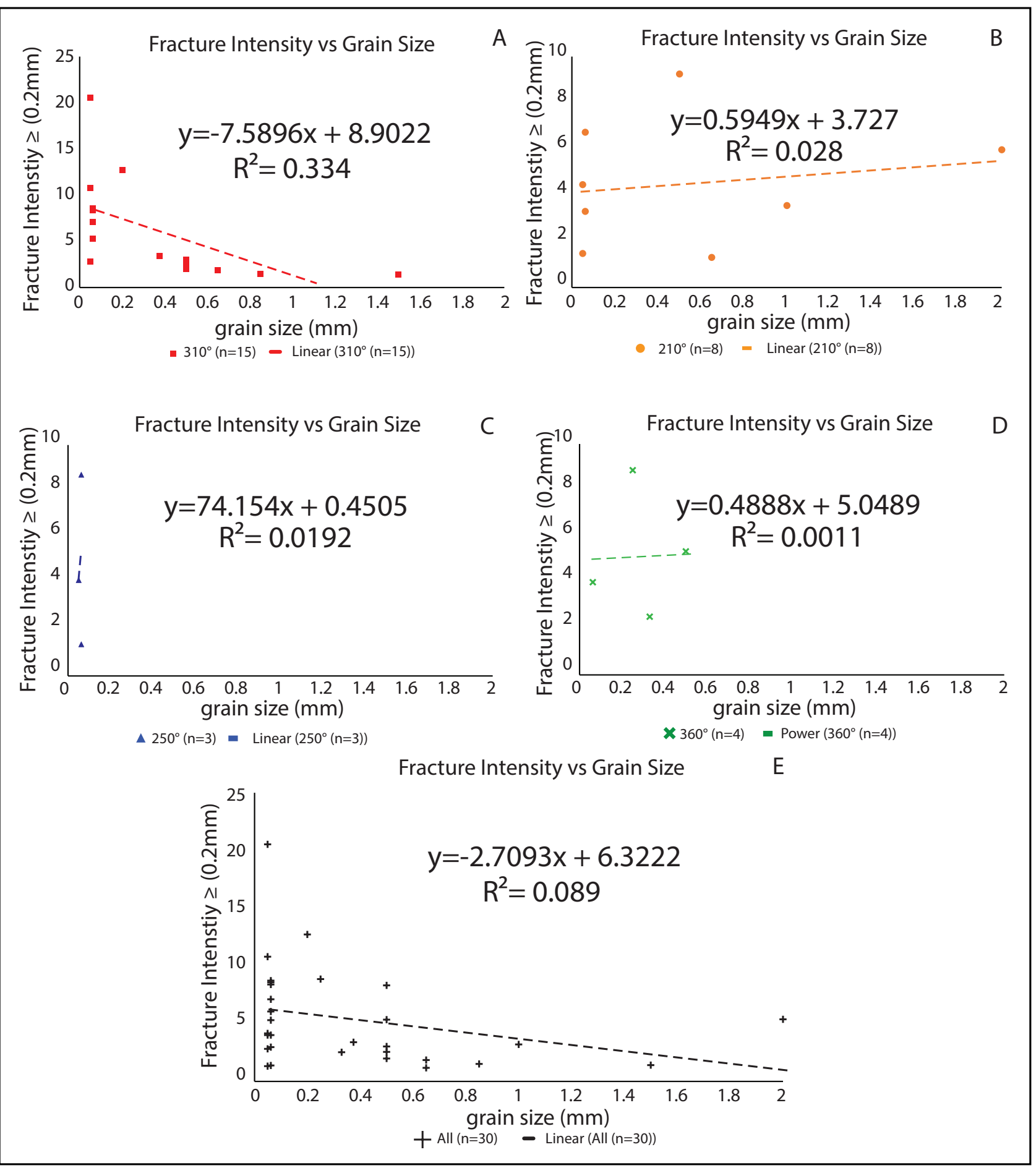

Figure 10. Plots showing fracture intensity $(F \geq 0.2 \mathrm{~mm})$ versus grain size. Fracture sets are labeled at top of figure. Both axes are logarithmic with grain size in millimeters on the $x$ axis and fracture intensity of 0.2 mm on the $y$ axis. Fracture intensity represents the expected number of fractures of a given size or larger per meter $(0.2 \mathrm{~mm}$ in this case). Regression line is shown as dashed line on graph. Refer to text for discussion. 


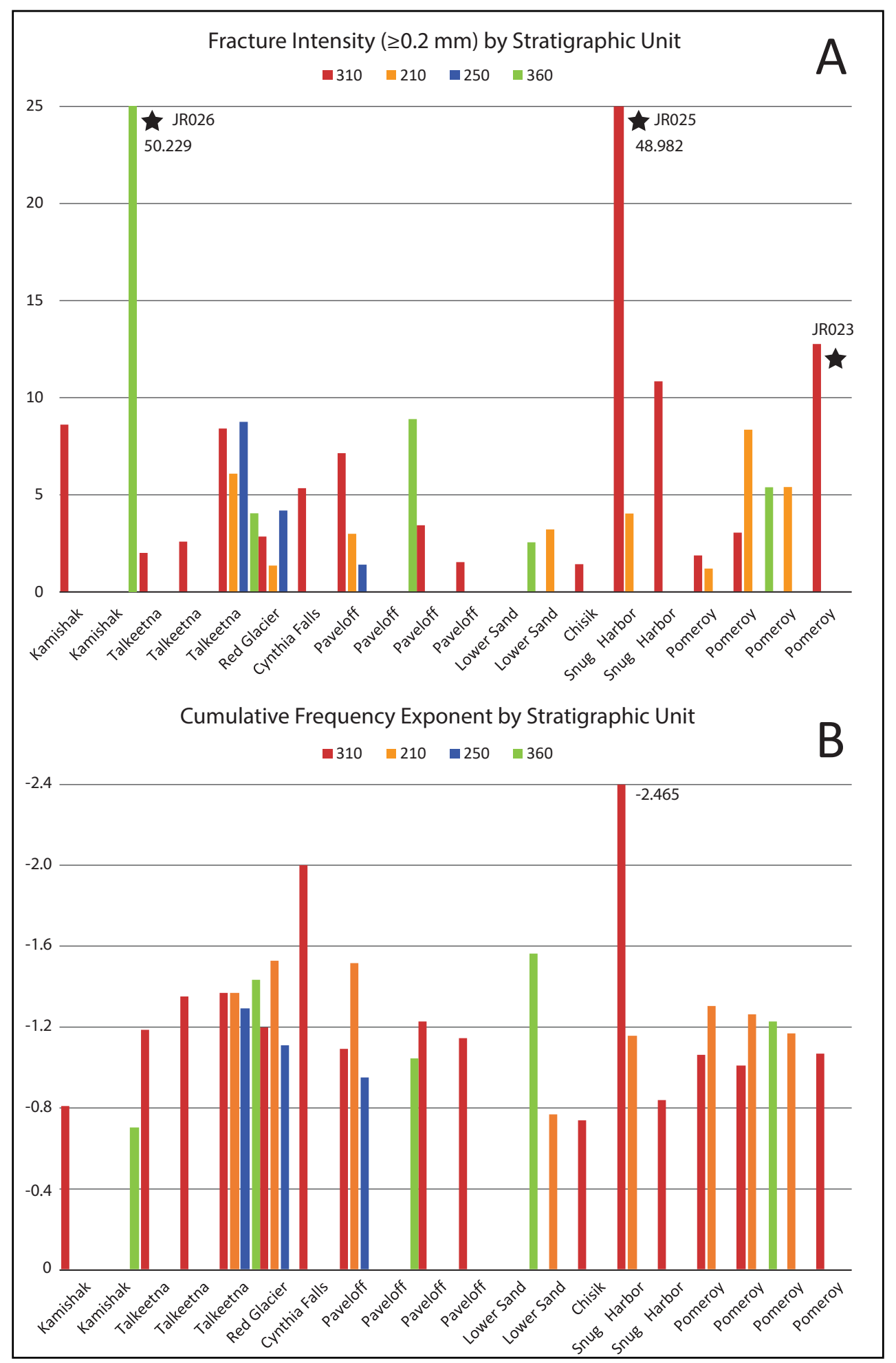

Figure 11. Histograms of fracture intensity and power-law exponent versus stratigraphic unit. Plots are organized and color-coded by fracture set and identified by stratigraphic unit, labeled on the $x$ axis. A. Fracture intensity of fractures $(F \geq 0.2 \mathrm{~mm}$ ) versus stratigraphic unit. Note one value from the Kamishak Formation is off-scale. Refer to text for discussion. Black stars denote stations with relatively high fracture intensities that are near faults. B. Power-law regression exponent versus stratigraphic unit. See text for discussion. 
Fracture intensity of the Mesozoic sedimentary forearc strata of lower Cook Inlet, Alaska 25

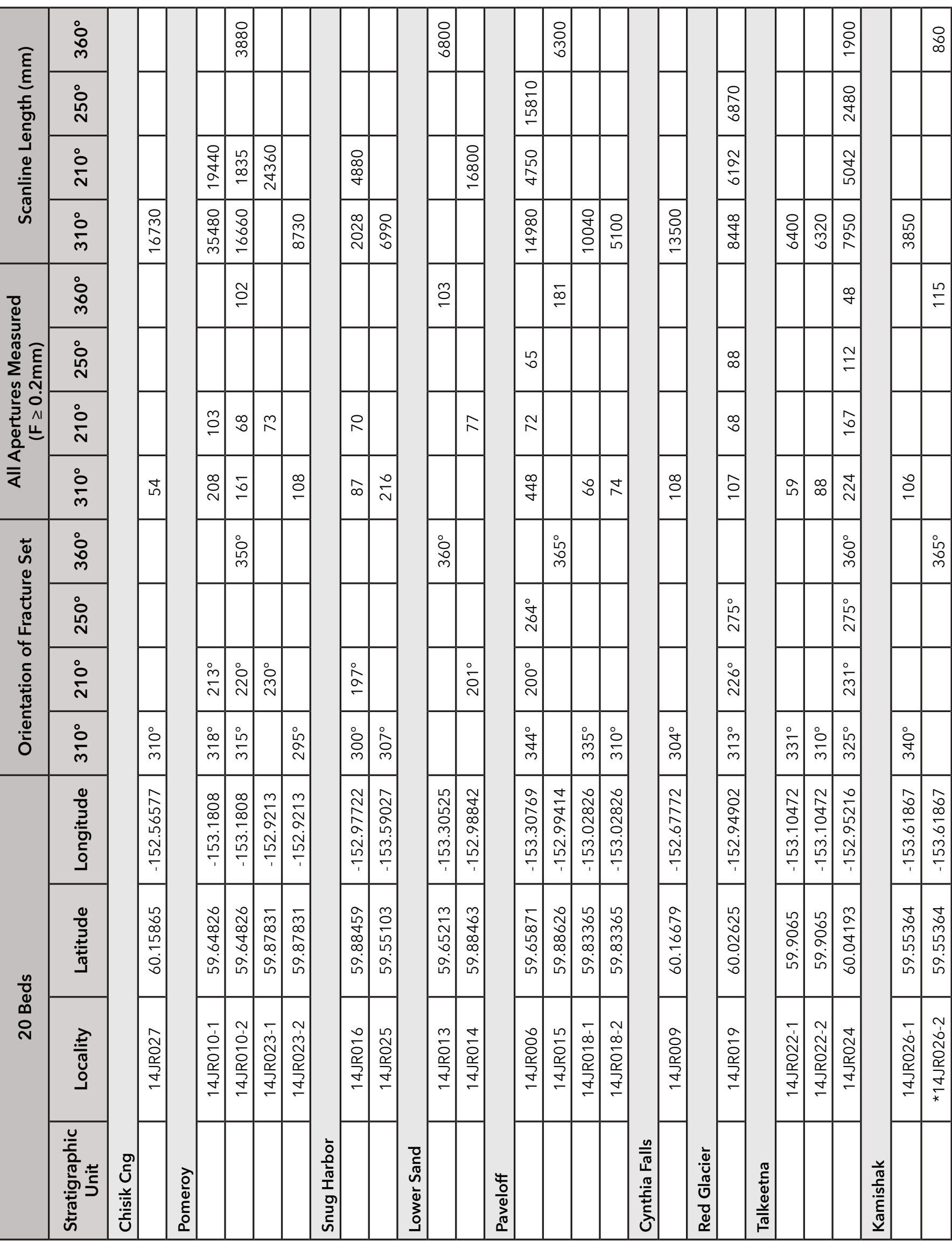




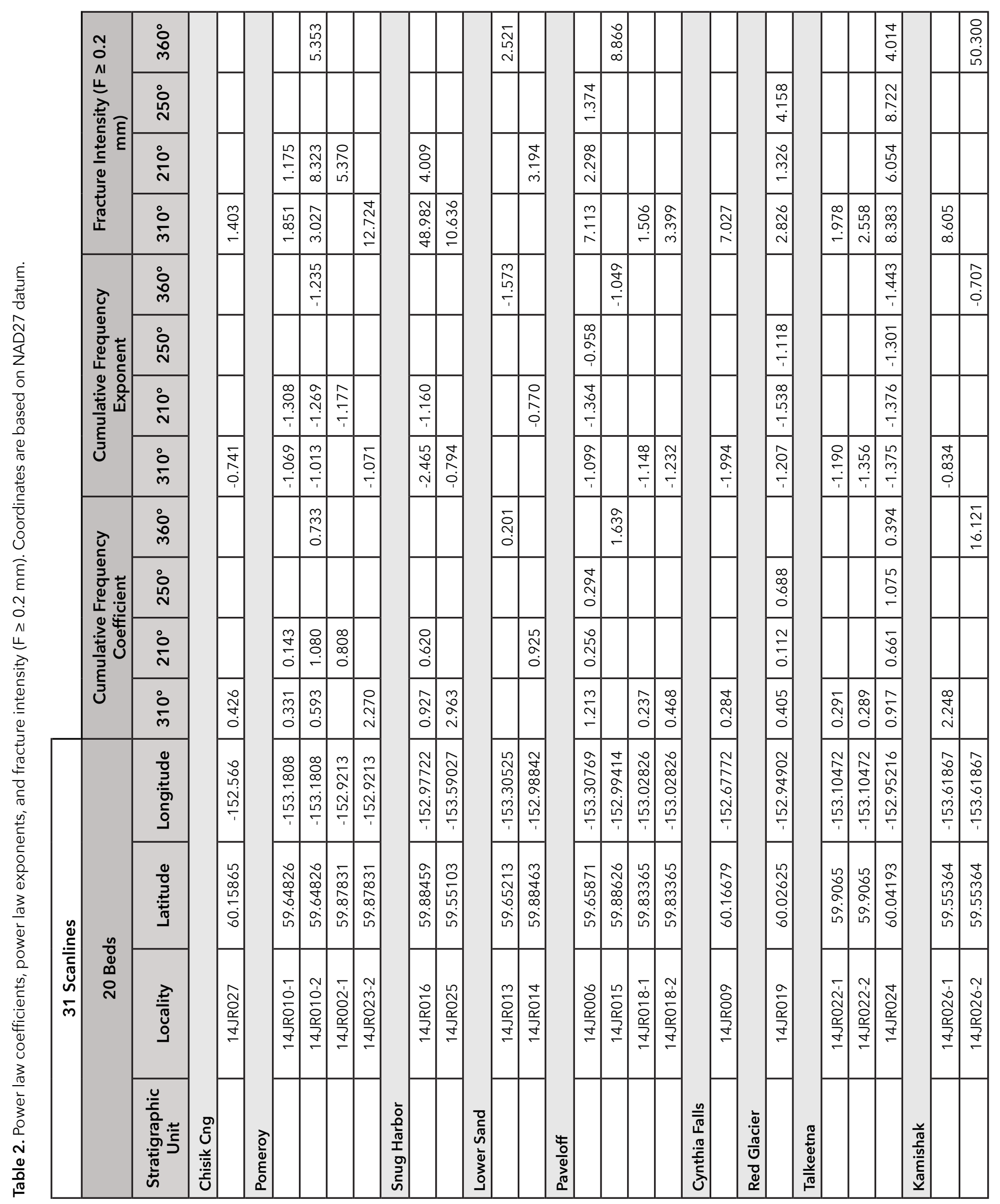


Fracture intensity of the Mesozoic sedimentary forearc strata of lower Cook Inlet, Alaska 27

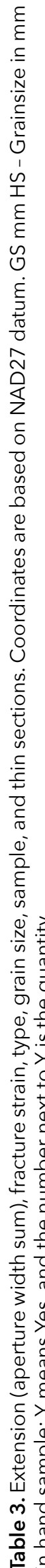

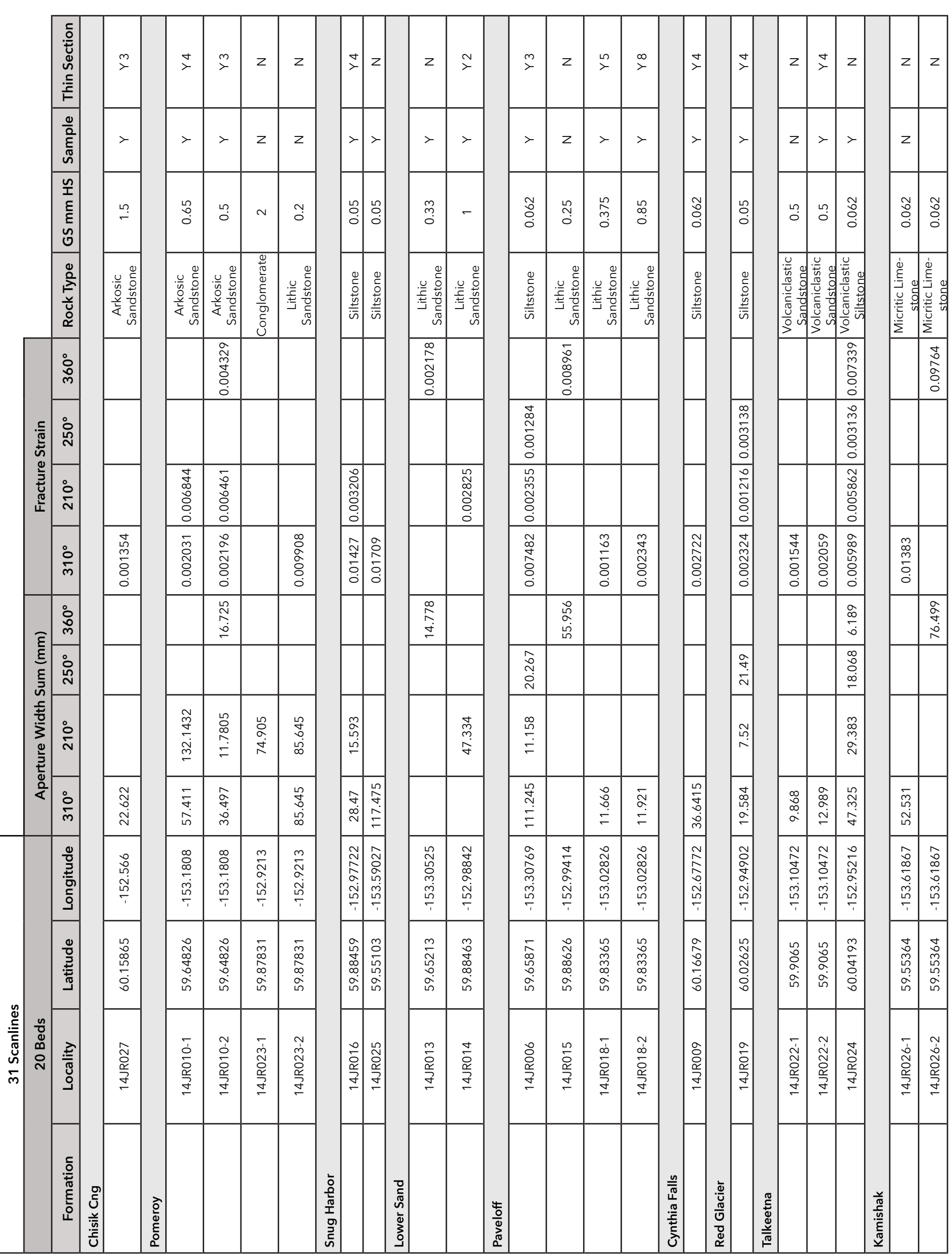




\section{Testing for correlation between fracture intensity, stratigraphic unit, and fracture set}

To evaluate how fracture intensity varies by stratigraphic unit and fracture set, we plotted histograms that show the fracture intensity ( $F$ greater than or equal to $0.2 \mathrm{~mm}$ ) and exponents of the least-squares regression equations for each fracture set and stratigraphic unit in the field area (fig. 11). Figure 11a shows the distribution of fracture intensity (F greater than or equal to $0.2 \mathrm{~mm}$ ). Fracture set $A$ generally has higher fracture intensities than the other fracture sets, followed by Set B, Set D, and Set $\mathrm{C}$. Fracture set $\mathrm{C}$ has the highest fracture intensity at two of the three stations where it was sampled. There is no apparent correlation between fracture intensity and stratigraphic unit; fracture intensities vary within all studied stratigraphic units-individual stratigraphic units contain both relatively high and low fracture intensities in similar strata. We note that three stations with the highest fracture intensities are near faults (such as the Bruin Bay fault; fig. 3). Thus, it is likely that faults locally increase the intensity of fracture sets.

Figure 11B shows all slopes (exponents) of power-law regressions from the cumulative frequency plots, and indicates that there is low variability across all stratigraphic units, with no apparent trend. Slopes generally range from -1 to -1.2 and seem to be well characterized by that exponent. Because the data do not demonstrate trends (such as consistently higher or lower fracture intensity [fig. 11A] or exponents [fig. 11B] within certain stratigraphic units), we conclude that fracture intensity is not controlled by lithologic changes across stratigraphic units.

To demonstrate the bulk distribution of fracture intensity in the study area, figure 12 shows histograms of fracture intensity (fig. 12A) (F greater than or equal to $0.2 \mathrm{~mm}$ ) as well as the slopes (exponents; fig. 12B) and coefficients (fig. 12C) of the regression equations for the study area. Fracture intensities for fractures with apertures greater than equal to $0.2 \mathrm{~mm}$ range from 1.17 to 20.54 , or one order of magnitude, and exhibit a positive skew with a mean intensity of 5.32. The fracture intensity exponents are approximately normally distributed with a slightly positive skew and a mean of -1.19. The power-law coefficients exhibit a positively skewed distribution with a significant number lying outside the distribution curve; the mean coefficient is 0.82 for the study area. The 95 percent confidence intervals of exponents and fracture intensity coefficients are $-1.19 \pm 0.50$ and $0.82 \pm 1.21$, respectively (figs. $12 \mathrm{~B}$ and C).

To further test the hypothesis that fracture intensity varies by fracture set, intensities for the four fracture sets were statistically analyzed using a box plot (fig. 13). The plot shows that while there is more variability in the $310^{\circ}$ fracture set (Set A), all four fracture sets generally overlap in median fracture intensity. The box plot tails show the range of fracture intensity for each set and the boxes show the first, second (median value), and third quartile of the distribution (fig. 13; table 4). The data suggest that fracture intensity does not vary significantly by fracture set.

\section{DISCUSSION}

In the previous section, we tested for correlations between fracture intensity ( $F$ greater than or equal to $0.2 \mathrm{~mm}$ ), power-law regression coefficients, and slopes, stratigraphic unit, grain size, and fracture set as well as spatial clustering of large fractures. We now discuss those results in the context of previous work.

We begin by offering explanations for the variations in fracture intensity in our field area. We then discuss variability in fracture intensity by outcrop, power-law regression slope by stratigraphic unit, and power-law scaling relationships. We conclude with implications for microfractures as predictors of macrofractures.

Results in the study area indicate that variation in fracture intensity does not correlate with grain size. Ortega and others (2010) correlate 
fracture intensity with dolomite content, mud content, and facies changes. It is therefore plausible that through further sedimentary analysis of the studied units, and using this study's data as a starting point, one might discover additional lithologic controls on fracture intensity. Possible lithologic controls could include cement type and percentage, matrix and framework composition, bedding style and thickness, and a host of other variables related to sediment provenance and depositional environment. However, there is little variation in fracture intensity across stratigraphic units that were deposited in different depositional environments in the field area (fig. 11). Thus, it is unlikely that variation in fracture intensity correlates with lithologic changes in the study area.
Alternatively, we postulate that fracture intensity differences likely stem from changes in local structural complexity, such as nearby faults (Savage and Brodsky, 2011) (figs. 3 and 11). Three stations sampled (14JR025, 14JR023, and 14JR026) were near known mapped faults, and had higher fracture intensities than stations sampled that were not near faults. High strain localized along faults and/or other large fractures could likely cause fractures of similar orientation to the larger fractures and faults to coalesce and locally increase the fracture density.

The slopes (exponents) of power-law regressions that quantify fracture intensity show little variation throughout the study area, with a small range in overall values (figs. 11 and 12). This suggests
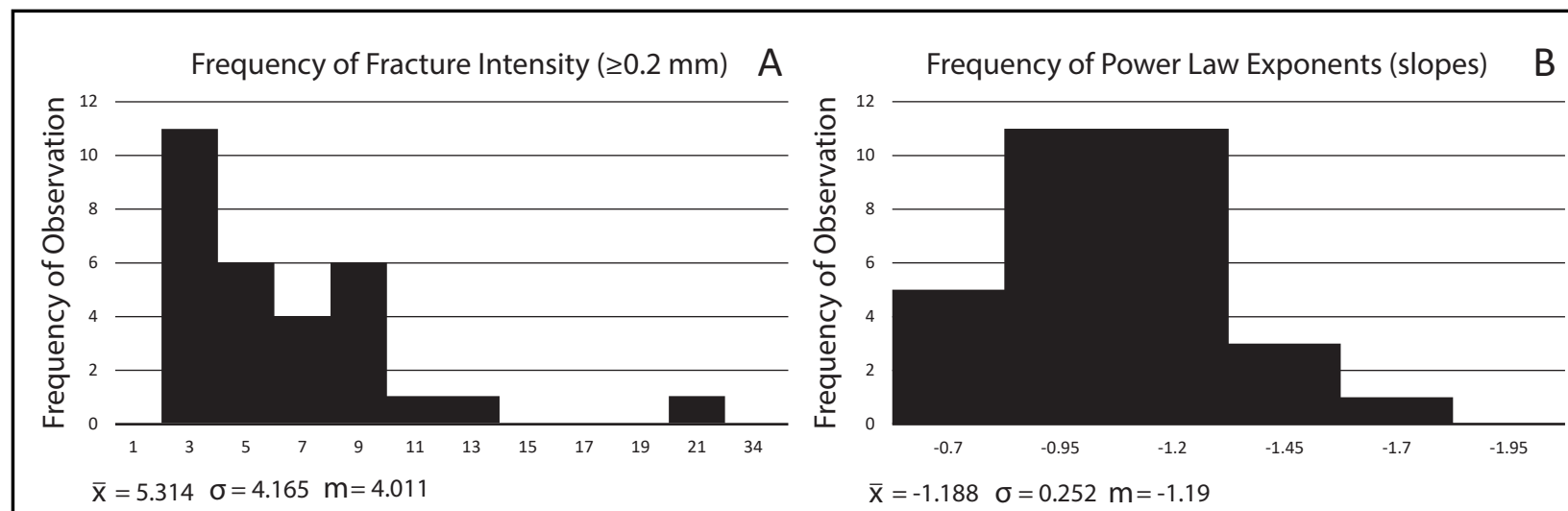

$\bar{x}=-1.188 \sigma=0.252 m=-1.19$

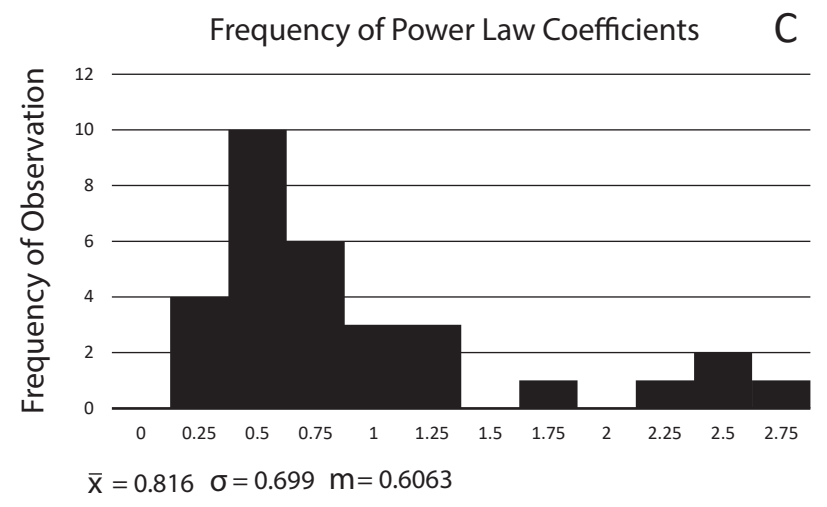

Figure 12. Histograms of fracture intensity, slope (power-law exponent), and coefficient, annotated with values of mean (barred $x$ ), standard deviation $(\sigma)$, and mode $(\mathrm{m})$. A. Fracture intensities $(F \geq 0.2 \mathrm{~mm}$ ) are not normally distributed, as evidenced by significant difference in median and mean. Distribution shows a significant tail to the right with a leftskewed peak. B. Frequency of slopes (power-law exponents) are approximately normally distributed, as evidenced by similar median and mean. There is a very slight left skew. C. Power-law coefficients are not normally distributed, showing significant outliers to the right with a strong left skew. Refer to text for discussion. 
that relative fracture frequency between fracture sizes (for example, ten small fractures per one big fracture) are consistent across a wide range of lithologies and locations in our field area. This observation is consistent with previous work on fracture intensity, which has proposed that one could use a universal scaling exponent for power-law correlations in specific rock types and regions (Hooker and others, 2014). Thus, given the consistency and normal distribution of slopes across our study area, we suggest that a universal scaling exponent could be used when discussing fracture intensities in the region. We propose that an exponent of -1.188 $( \pm 0.504)$ could accurately estimate 95 percent of slopes for power-law regressions in Cook Inlet.

Microfracture widths in our samples span 2.5 orders of magnitude and generally show stronger truncation and observation biases than the macrofracture data (fig. 9). Due to limitations in resolution, we could not measure the smallest microfractures. Thus, we could potentially miss, and therefore not quantify, the true abundance of microfractures (for example, Hooker and others, 2014). Large fractures were rare in our thin sections, likely because the samples we collected were often plucked from the margins of preexisting macrofractures in the field, statistically reducing the likelihood of their presence in our samples.

The exponents and coefficients of the regression equations for microfractures are well within the 95 percent confidence interval for slopes and coefficients established by outcrop analysis of macrofractures.

Projecting the power-law regressions established from microfractures into the domain of

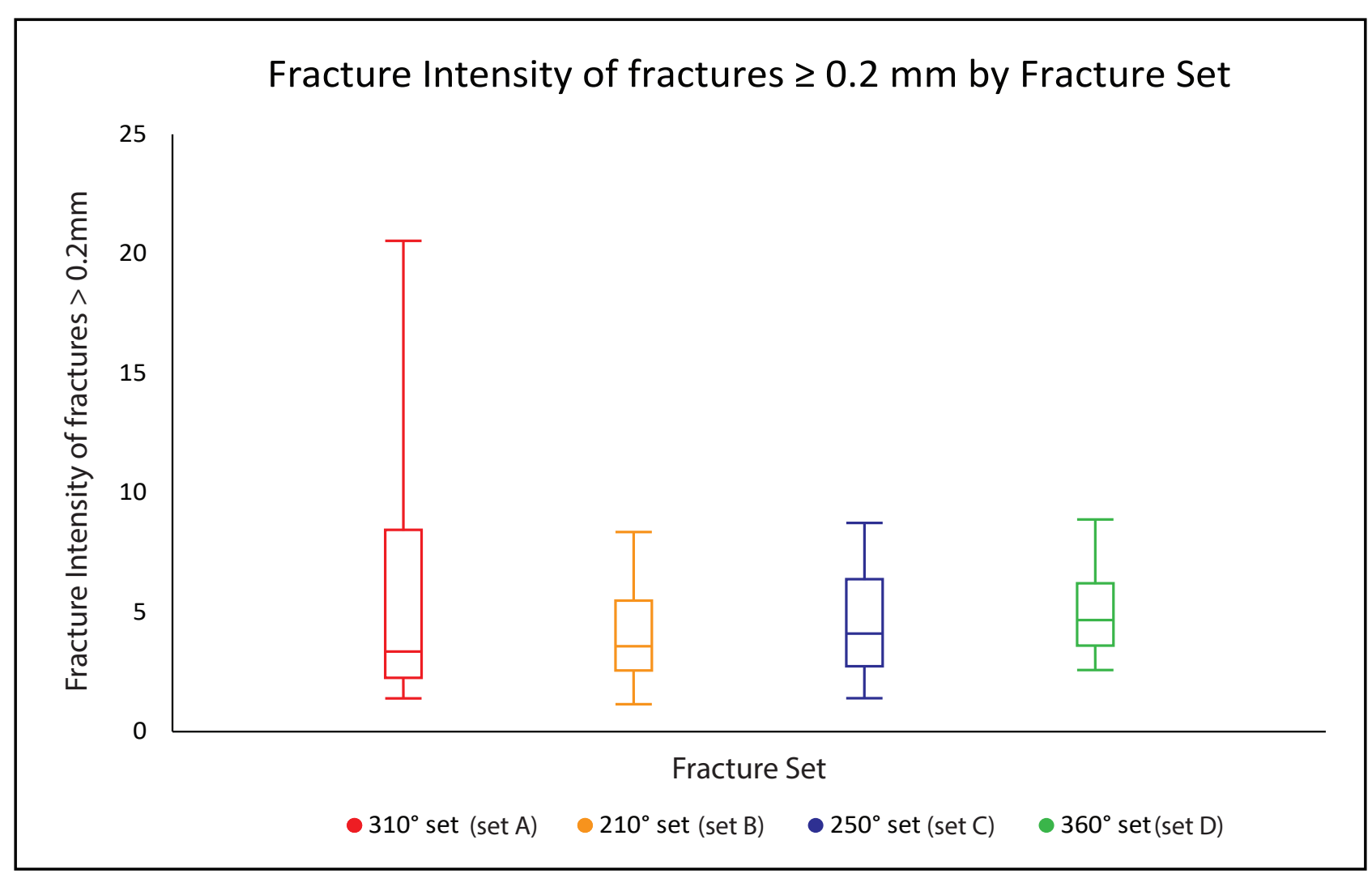

Figure 13. Box plots for fracture intensities $(F \geq 0.2 \mathrm{~mm})$ for the four fracture sets. Minimum and maximum intensities shown with tails; first, second, and third quartiles are shown by boxes, with the lower margin of the box representing the first quartile, middle representing the second quartile, and the top of the box representing the third quartile. The data suggest that fracture intensity does not vary significantly by fracture set. 
Table 4. Fracture intensity statistics by set.

\begin{tabular}{|l|c|c|c|c|}
\hline Fracture Set & $\mathbf{3 1 0 ^ { \circ }}(\mathbf{S e t} \mathbf{A})$ & $\mathbf{2 1 0 ^ { \circ }}(\mathbf{S e t} \mathrm{B})$ & $\mathbf{2 5 0 ^ { \circ }}(\mathbf{S e t} \mathbf{C})$ & $\mathbf{3 6 0 ^ { \circ }}(\mathbf{S e t} \mathrm{D})$ \\
\hline Maximum & 20.54 & 8.32 & 8.72 & 8.87 \\
\hline Quartile 3 & 8.48 & 5.54 & 6.44 & 6.23 \\
\hline Median & 3.40 & 3.60 & 4.16 & 4.68 \\
\hline Quartile 1 & 2.27 & 2.56 & 2.77 & 3.64 \\
\hline Minimum & 1.40 & 1.17 & 1.37 & 2.52 \\
\hline Average & 6.133 & 4.05 & 4.75 & 5.19 \\
\hline $\mathrm{n}=$ & 15 & 8 & 3 & 5 \\
\hline
\end{tabular}

macrofractures demonstrates that by measuring the former, we can aptly characterize the latter of the same fracture set (fig. 9). Thus, one could accurately estimate macrofracture abundance (and therefore better characterize fluid flow) by measuring microfractures. Consequently, because measuring macrofractures in the subsurface is difficult (for example, Narr and Suppe, 1991; Laubach, 2003), one could measure microfractures in core and accurately estimate macrofracture intensities in the subsurface.

We did not sample fractures from subsurface core; however, previous workers have established that microfractures can be used to predict macrofracture abundances based on measurements from subsurface core (Hooker and others, 2014). Fractures are commonly filled with minerals precipitated from fluids circulating through fractures in the subsurface. Thus, we infer that filled fractures exposed in the study area likely formed at depth. Despite not being filled, the microfractures we sampled show strong correlations in spacing and relative frequency with the filled macrofractures at the surface. We therefore suggest that while microfractures are not important for fluid flow (Laubach, 1997), they can serve as a proxy for estimating macrofracture distributions, which are important for understanding fluid flow in reservoirs. We conclude that microfracture intensity measured in core may be a useful indicator of macrofracture intensity in the subsurface.
Our results indicate that in feldspathic and lithic sandstones, fracture size distributions can be quantified using cumulative frequency plots and power-law regressions (figs. 8 and 9). Our observations suggest that micro- and macrofractures in the lithic and feldspathic sandstones follow power-law scaling relationships across five orders of magnitude in a given fracture set (fig. 9). This is consistent with previous work on scaling relationships of micro- and macrofractures (Marrett and others, 1999; Hooker and others, 2009, 2014).

Fracture strain values showed a moderate correlation with fracture intensity values, and on the whole were consistent with strain magnitudes reported in other studies (for example, Hooker and others, 2009; Inigo and others, 2012). Minimal analysis was done with these values, limiting our ability to interpret them.

\section{CONCLUSIONS}

Average fracture intensities for fractures with apertures greater than equal to $0.2 \mathrm{~mm}$ in the $310^{\circ}$ (Set A), $210^{\circ}$ (Set B), $250^{\circ}$ (Set C), and $360^{\circ}$ (Set D) fracture sets are 6.13, 4.05, 4.75, and 5.19, respectively. These fracture sets share similar fracture intensities with a similar range of values from the first quartile (Q1) through the third quartile (Q3) (fig. 13). Set A has the highest recorded fracture intensity as well as the largest range. Power-law regression slopes that quantify the size-normalized cumulative frequency plots 
suggest that the range and relative frequency of fracture sizes are similar for all stratigraphic units across the study area (figs. 11 and 12). We suggest that, for future regression calculations in the area, a scaling exponent of $-1.19( \pm 0.50)$ would accurately quantify 95 percent of the slopes. Grain size does not correlate with fracture intensity in the studied strata and thus fracture intensity must be controlled by other variables.

We speculate that lithologic parameters such as cement percentage, cement type, and depositional facies characteristics might show a stronger correlation with fracture intensity, and that these variables should be considered for future work. Fracture intensity locally increases near faults or other large fractures. Two outcrops (14JR025 and 14JR026) near the Bruin Bay fault show the highest fracture intensity in the study, while one outcrop (14JR023) near a small cross fault also shows higher fracture intensity. We suggest that as fractures and faults open through progressive coalescence of smaller fractures, stress continues to accumulate in the surrounding rock body. With the accumulated stress, other fractures form and leave residual permanent strain that localizes near stressed areas, such as faults and large fractures. Thus, regions near large fractures or small faults would most likely serve as locations for concentrated subsurface fluid flow during deformation and until the fractures are mineralized.

Microfractures studied in thin section can be used as a proxy for determining the fracture intensity of macrofractures at outcrop or hand-sample scale within an order of magnitude (fig. 9). Our results also show that feldspathic and lithic sandstones and siltstones follow power-law spacing relationships across five orders of magnitude, similar to other previously studied lithologies (Marrett and others, 1999; Ortega and others, 2010; Hooker and others, 2014).

Although there is little variation in fracture intensities between sets, the average fracture intensity for the $310^{\circ}$ fracture set (Set $\mathrm{A}$ ) is slightly greater than the others and has the largest range in fracture intensity (table 4). Set $\mathrm{A}$ is also the most likely to open or reopen under the modern stress regime (Ruppert, 2008). Therefore, we suggest that fracture set A likely has the greatest influence on fluid migration in Cook Inlet basin. Absolute ages of this fracture set are difficult to determine; they occur in strata as old as Triassic (Kamishak Formation) and as young as Paleogene (Hemlock(?) Formation). It is likely that Set A fractures developed or continued developing as extension joints during Miocene and younger collision of the Yakutat block (for example, LePain and others, 2013). However, fluid migration in Cook Inlet basin may also have been facilitated by fractures formed during an earlier deformation (for example, the event responsible for the uplift, erosion, and unconformity separating the Mesozoic and Cenozoic strata throughout the basin).

In this example, we conclude that rock type, stratigraphic unit, and grain size show no correlation with fracture intensity, and it is likely that structural position plays the largest role in a rock's fracture intensity (for example, Savage and Brodsky, 2011). We demonstrate that scan lines on microscopic fractures correlate well with scan lines in macroscopic fractures. Studying microfractures could allow one to accurately characterize macrofracture abundance at the reservoir scale. This is extremely useful because measuring subsurface fractures is necessary but notoriously difficult, and therefore, one could measure microscopic fractures from core samples, and accurately characterize subsurface fracture populations. Furthermore, in Cook Inlet, these subsurface fractures are the most likely migration pathways for hydrocarbons, as the rocks of the lower Cook Inlet are characterized by low permeability (Helmold and others, 2013).

\section{FUTURE WORK}

While we demonstrate a correlation between macrofractures and microfractures at the surface, it would also be useful to correlate microfractures from subsurface cores with macrofractures from outcrop samples. Although the filled fractures 
found at outcrops imply a subsurface origin, it is still uncertain what caused the fractures to fill, and at what depth they were filled. If the mechanism for fracture fill was near-surface groundwater mixing with connate water in the subsurface, then it is possible that the majority of fractures in the subsurface remain open pathways for fluid flow. These two research ideas (understanding fracture fill mechanisms and subsurface microfractures) would be excellent objectives for future work related to the subsurface reservoir potential of lower Cook Inlet. Additionally, this data set would be amendable to analysis of fracture spatial arrangements after Marret and others (2017) and additional fracture strain analysis after Inigo and others (2012).

\section{ACKNOWLEDGMENTS}

Discussions with Anupma Prakash, Jeff Benowitz, and Marwan Wartes, and technical reviews by Paul Decker and an anonymous reviewer guided and improved this manuscript. We thank the owners and operators of Bear Mountain Lodge and Snug Harbor Wilderness Lodge for their hospitality while we conducted field work for this project. Helicopter support was provided by Pathfinder Aviation and pilot Spanky (Merlin) Handley. Alaska Air Taxi and Regal Air provided fixed-wing support. This report was distilled from a University of Alaska Fairbanks Master of Science thesis by Rosenthal, which was partially funded by the Alaska Division of Geological \& Geophysical Surveys. 


\section{REFERENCES}

Alaska Oil and Gas Conservation Commission (AOGCC), 2015, Well history files on-line database. Last accessed November 17, 2015. http:// aogweb.state.ak.us/WebLink8/Browse.aspx?dbid $=0$

Anders, M. H., S. E. Laubach, and C. H. Scholz, 2014, Microfractures: A review: Journal of Structural Geology. http://doi.org/10.1016/j. jsg.2014.05.011

Betka, P.M., and Gillis, R.J., 2015, The superposition of strike-slip and reverse-slip faults in the Bruin Bay fault system, Ursus Head, lower Cook Inlet, in Wartes, M.A., ed., Energy-related studies during the 2014 field season, western Cook Inlet, Alaska: Alaska Division of Geological \& Geophysical Surveys Preliminary Interpretive Report 2015-5-2, p. 5-8. http://doi. org/10.14509/29457

Betka, P.M., and Gillis, R.J., 2014a, Preliminary characterization of brittle deformation on the Iniskin Peninsula-Implications for the kinematic history of the Bruin Bay fault system, lower Cook Inlet, Alaska: Alaska Division of Geological \& Geophysical Surveys Preliminary Interpretive Report 2014-5, 14 p. http://doi. org/10.14509/29130

Betka, P.M., and Gillis, R.J., 2014b, Preliminary kinematic evidence for right-lateral slip along a system of steeply dipping faults in the hanging wall of the Bruin Bay fault, Iniskin Peninsula, lower Cook Inlet, Alaska, in Gillis, R.J., ed., Cook Inlet program 2013 field studies_-Observations and preliminary interpretations from new 1:63,360-scale geologic mapping of the Iniskin Peninsula, lower Cook Inlet, Alaska: Alaska Division of Geological \& Geophysical Surveys Preliminary Interpretive Report 2014-24, p. 17-22. http://doi.org/10.14509coe/27309 Betka, P.M., and Gillis, R.J., submitted (2017), Polyphase slip history of the Bruin Bay fault system, southern Alaska: Alaska Division of Geological \& Geophysical Surveys Report of Investigation.

Betka, P.M., Gillis, R.J., and Benowitz, J.A., accepted (2017), The Bruin Bay fault system of southern Alaska-A Mesozoic-Cenozoic tec- tonic boundary with a polyphase fault-slip history, Iniskin-Tuxedni region, Cook Inlet, Alaska: Geosphere.

Blasko, D.P., 1976, Oil and gas seeps in Alaska, Alaska Peninsula, western Gulf of Alaska: U.S. Bureau of Mines Report of Investigations 8122, 80 p. http://www.dggs.alaska.gov/pubs/id/29150 Bradley, D.C., Kusky, T.M., Haeussler, P.J., Goldfarb, R.J., Miller, M.L., Dumoulin, J.A., Nelson, S.W., and Karl, S.M., 2003, Geologic signature of early Tertiary ridge subduction in Alaska, in Sisson, V.B., Roeske, S.M., and Pavlis, T.L., eds., Geology of a transpressional orogen developed during ridge-trench interaction along the North Pacific Margin: Geological Society of America Special Paper 371, p. 19-49. http://doi.org/ doi:10.1130/0-8137-2371-X.19

Bruhn, R.L., and Haeussler, P.J., 2006, Deformation driven by subduction and microplate collision-Geodynamics of Cook Inlet basin, Alaska: Geological Society of America Bulletin, v. 118, no.3-4, p. 289-303. http://doi.org/doi:10.1130/ B25672.1

Clift, P.D., Draut, A.E., Kelemen, P.B., Blusztajn, Jerzy, and Greene, Andrew, 2005, Stratigraphic and geochemical evolution of an oceanic arc upper crustal section-The Jurassic Talkeetna Volcanic Formation, south-central Alaska: Geological Society of America Bulletin, v. 117, no. 7/8, p. 902-925. http://doi.org/10.1130/ B25638.1

Coe, R.S., Globerman, B.R., Plumley, P.W., and Thrupp, G.A., 1985, Paleomagnetic results from Alaska and their tectonic implications, in Howell, D.G., ed., Tectonostratigraphic terranes of the circum-Pacific region: CircumPacific Council for Energy and Mineral Resources, Earth Science Series, no. 1, p. 85-108.

Detterman, R.L., and Hartsock, J.K., 1966, Geology of the Iniskin-Tuxedni Peninsula region, Alaska: U.S. Geological Survey Professional Paper 512, 78 p., 7 plates. https://pubs.er.usgs. gov/publication/pp512

Dickinson, W.R., 1995, Forearc basins, in Busby, C.J., and Ingersoll, R.V., eds., Tectonics of sedimentary basins: Oxford, Blackwell Science, p. 221-261. 
Engebretson, D.C., Cox, Allan, and Gordon, R.G., 1985, Relative motions between oceanic and continental plates in the Pacific basin: Boulder, Colorado, Geological Society of America Special Paper 206, p. 1-60. http://doi.org/10.1130/ SPE206-p1

Engelder, Terry, Lash, G.G., and Uzcátegui, R.S., 2009, Joint sets that enhance production from Middle and Upper Devonian gas shales of the Appalachian Basin: American Association of Petroleum Bulletin, v. 93, no. 7, p. 857-889. http://doi.org/10.1306/03230908032

Fisher, M.A., and Magoon, L.B., 1978, Geologic framework of lower Cook Inlet, Alaska: American Association of Petroleum Geologists Bulletin, v. 62, no. 3, p. 373-402. http://doi.org/10.1306/ C1EA4851-16C9-11D7-8645000102C1865D

Fletcher, H.J., and Freymueller, J.T., 2003, New constraints on the motion of the Fairweather fault, Alaska, from GPS observations: Geophysical Research Letters, v. 30, p. 1,139. http://doi. org/10.1029/2002GL016476

Gillis, R.J., Wartes, M.A., and O'Sullivan, P.B., 2011, Preliminary findings from reconnaissance structural studies along the Bruin Bay fault system and adjacent areas, south-central Alaska: American Association of Petroleum Geologists Pacific Section Meeting, Anchorage, Alaska, May 10, 2011: Alaska Division of Geological \& Geophysical Surveys, 1 sheet. http://doi. org/10.14509/23403

Gillis, R.J., Maley, M.R., Frohman, R.A., and Peterson, C.S., 2013a, Fracture studies in Upper Cretaceous and Upper Jurassic strata on the upper Alaska Peninsula and lower Cook Inlet, in Gillis, R.J., ed., Overview of 2012 field studiesUpper Alaska Peninsula and west side of lower Cook Inlet, Alaska: Alaska Division of Geological \& Geophysical Surveys Preliminary Interpretive Report 2013-1D, p. 13-17. http://doi. org/10.14509/24847

Gillis, R.J., Swenson, R.F., Wartes, M.A., and Frohman, R.A., 2013b, Reconnaissance investigations of the Bruin Bay fault system along the western margin of lower Cook Inlet and upper Alaska Peninsula, in Gillis, R.J., ed., Overview of 2012 field studies-Upper Alaska Peninsula and west side of lower Cook Inlet, Alaska: Alaska Division of Geological \& Geophysical Surveys Preliminary Interpretive Report 2013-1G, p. 33-37. http://doi.org/10.14509/24850

Gillis, R.J., 2016, Discovery of a new sandstone with residual oil in Maastrichtian(?) strata at Shelter Creek, lower Cook Inlet, Alaska, in Herriott, T.M., ed., Petroleum-related geologic studies in lower Cook Inlet during 2015, Iniskin-Tuxedni region, south-central Alaska: Alaska Division of Geological \& Geophysical Surveys Preliminary Interpretive Report 2016-1-7, p. 51-58.

Gomez, L.A., and Laubach, S.E., 2006, Rapid digital quantification of microfracture populations: Journal of Structural Geology, v. 28, no. 3, p. 408-420. http://doi.org/10.1016/j. jsg.2005.12.006

Helmold, K.P., LePain, D.L., Wilson, M.D., and Peterson, C.S., 2013, Petrology and reservoir potential of Tertiary and Mesozoic sandstones, Cook Inlet, Alaska-A preliminary analysis of outcrop samples collected during 2007-2010 field seasons: Alaska Division of Geological \& Geophysical Surveys Preliminary Interpretive Report 2013-5, 34 p. http://doi. org/10.14509/25035

Herriot, T.M., Wartes, M.A., and Decker, P.L., 2016, Record of a Late Jurassic deep-water canyon at Chisik Island, south-central AlaskaFurther delineation of Naknek Formation depositional systems in lower Cook Inlet, in Herriott, T.M., ed., Petroleum-related geologic studies in lower Cook Inlet during 2015, Iniskin-Tuxedni region, south-central Alaska: Alaska Division of Geological \& Geophysical Surveys Preliminary Interpretive Report 2016-1-6, p. 45-49. http:// doi.org/10.14509/29540

Herriott, T.M., and Wartes, M.A., 2017, Discovery of a 35-meter-thick, oil-stained sandstone interval in outcrop of the Tonnie Siltstone Member, Chinitna Formation, lower Cook Inlet, south-central Alaska: Alaska Division of Geological \& Geophysical Surveys Preliminary Interpretive Report 2017-5, 12 p. 
Hooker, J.N., Gale, J.F.W., Gomez, L.A., Laubach, S.E., Marrettt, R., and Reed, R.M., 2009, Aperture-size scaling variations in a low-strain opening-mode fracture set, Cozzette Sandstone, Colorado: Journal of Structural Geology, v. 31, no. 7, p. 707-718. http://dx.doi.org/10.1016/j. jsg.2009.04.001

Hooker, J.N., Laubach, S.E., and Marrettt, R., 2014, A universal power-law scaling exponent for fracture apertures in sandstones: Geological Society of America Bulletin, v. 126, no. 9-10, p. 1,340-1,362. http://doi.org/10.1130/B30945.1

Klimczak, C., Schultz, R.A., Parashar, R., Reeves, D.M., 2009, Cubic law with aperture-length correlation: implications for network scale fluid flow, Hydrogeology Journal, 18 (2010), p. 851-862.

Kirschner, C.E., and Lyon, C.A., 1973, Stratigraphic and tectonic development of Cook Inlet petroleum province, in Arctic Geology: American Association of Petroleum Geologists Memoir, v. 19, p. 396-407. http://archives. datapages.com/data/specpubs/history3/data/ a108/a108/0001/0350/0396.htm

Laubach, S. E., Olson, J. E, and Gross, M. R., 2009. Mechanical and fracture stratigraphy. AAPG Bulletin 93(11), p. 1,413-1,426. http:// doi.org/10.1306/07270909094

Laubach, S.E., 2003, Practical approaches to identifying sealed and open fractures: American Association of Petroleum Geologists Bulletin, v. 87, no. 4, p. 561-579.

Laubach, S.E., 1997, A method to detect natural fracture strike in sandstones: American Association of Petroleum Geologists Bulletin, v. 81, no. 4, p. 604-623.

LePain, D.L., Stanley, R.G., and Helmold, K.P., 2016, Reconnaissance stratigraphy of the Red Glacier Formation (Middle Jurassic) near Hungryman Creek, Cook Inlet basin, Alaska, in Herriott, T.M., ed., Petroleum-related geologic studies in lower Cook Inlet during 2015, Iniskin-Tuxedni region, south-central Alaska: Alaska Division of Geological \& Geophysical Surveys Preliminary Interpretive Report 2016-13, p. 21-31.
LePain, D.L., Stanley, R.G., Gillis, R.J., Helmold, K.P., Peterson, C.S., and Wartes, M.A., 2011, Deposition of Middle Jurassic Tuxedni Group, lower Cook Inlet, Alaska-Initial exhumation of an Early Jurassic island arc and incipient motion on the Bruin Bay fault zone: Program with Abstracts, American Association of Petroleum Geologists Pacific Section Annual Meeting, p. 71. LePain, D.L., Stanley, R.G., Helmold, K.P., and Shellenbaum, D.P., 2013, Geologic framework and petroleum systems of Cook Inlet basin, south-central Alaska, in Hite, D.M., and Stone, D.M., eds., Oil and gas fields of the Cook Inlet basin, Alaska: American Association of Petroleum Geologists Memoir, v. 104, p. 37-116.

Lianbo, Zeng, and Xiang-Yang, Li, 2009, Fractures in sandstone reservoirs with ultra-low permeability-A case study of the Upper Triassic Yanchang Formation in the Ordos Basin, China: American Association of Petroleum Geologists Bulletin, v. 93, no. 4, p. 461-477. http://doi. org/10.1306/09240808047

Lillis, P.G., and Stanley, R.G., 201 1, Petroleum generation modeling for Cook Inlet Basin, Alaska: American Association of Petroleum Geologists, Program with Abstracts, \#90125, Pacific Section Annual Meeting, Anchorage, AK, May 8-11, 2011, p. 72.

Magoon, L.B., 1994, Tuxedni-Hemlock(!) petroleum system in Cook Inlet, Alaska, in The petroleum system-From source to trap: American Association of Petroleum Geologists Memoirs, v. 60, p. 359-370.

Magoon, L.B., and Claypool, G.E., 1981, Petroleum geology of Cook Inlet basin-An exploration model: American Association of Petroleum Bulletin, v. 65, no. 6, p. 1,043-1,061.

Magoon, L.B., Adkison, W.L., and Egbert, R.M., 1976, Map showing geology, wildcat wells, Tertiary plant fossil localities, $\mathrm{K}-\mathrm{Ar}$ age dates, and petroleum operations, Cook Inlet area, Alaska: U.S. Geological Survey Miscellaneous Investigations Series, Map I-1019, scale 1:250,000, 3 sheets. https://pubs.er.usgs.gov/publication/ i1019 
Marrett, R., Gale, J.F.W., Gomez, L.A., Laubach, S.E., 2017, Correlation analysis of fracture arrangement in space, Journal of Structural Geology, 108 (2018) p. 16-33.

Marrett, R., Ortega, O.J., and Kelsey, C.M., 1999, Extent of power-law scaling for natural fractures in rock: Geology, v. 27, no. 9, p. 799-802. http://doi.org/10.1130/0091-7613(1999)027<0 799:EOPLSF>2.3.CO;2

Narr, W., 1991, Fracture density in the deep subsurface-Techniques with application to Point Arguello oil field: American Association of Petroleum Geologists Bulletin, v. 75, no. 8, p. 1,3001,323 .

Narr, W., and Suppe, J., 1991, Joint spacing in sedimentary rocks: Journal of Structural Geology, v. 13, no. 9, p. 1,037-1,048. http://doi. org/10.1016/0191-8141(91)90055-N

Nelson, R. A., 1985, Geologic analysis of naturally fractured reservoirs: Houston, Gulf Publishing, $320 \mathrm{p}$.

Nokleberg, W.J., Plafker, George, and Wilson, F.H., 1994, Geology of south-central Alaska, in Plafker, George, and Berg, H.C., eds., The geology of Alaska: Geological Society of America, The geology of North America, v. G-1, p. 311-366.

Ortega, O.J., and Marrett, R.A., 2000, Prediction of macrofracture properties using microfracture information, Mesaverde Group sandstones, San Juan basin, New Mexico: Journal of Structural Geology, v. 22, no. 5, p. 571-588. http://doi. org/10.1016/S0191-8141(99)00186-8

Ortega, O.J., Gale, J.F.W., and Marrettt, Randall, 2010, Quantifying diagenetic and stratigraphic controls on fracture intensity in platform carbonates-An example from the Sierra Madre Oriental, northeast Mexico: Journal of Structural Geology, v. 32, no. 12, p. 1,943-1,959. http:// doi.org/10.1016/j.jsg.2010.07.004

Ortega, O.J., Marrett, R.A., and Laubach, S.E., 2006, A scale-independent approach to fracture intensity and average spacing measurement: American Association of Petroleum Geologists Bulletin, v. 90, no. 2, p. 193-208. http://doi. org/10.1306/08250505059

Plafker, George, Moore, J.C., and Winkler, G.R.,
1994, Geology of the southern Alaska margin, in Plafker, George, and Berg, H.C., eds., The Geology of Alaska: Boulder, Colorado, Geological Society of America, Geology of North America, v. G-1, p. 389-450.

Plafker, George, Nokleberg, W.J., and Lull, J.S., 1989, Bedrock geology and tectonic evolution of the Wrangellia, Peninsular, and Chugach terranes along the Trans-Alaskan Crustal Transect in the northern Chugach Mountains and southern Copper River basin, Alaska: Journal of Geophysical Research, v. 94, no. B4, p. 4,255-4,295. http://doi.org/10.1029/JB094iB04p04255

Pollard, D.D., and Segall, Paul, 1987, Theoretical displacements and stresses near fractures in rock-With applications to faults, joints, veins, dikes, and solution surfaces: Fracture Mechanics of Rock, p. 277-349. http://dx.doi.org/10.1016/ B978-0-12-066266-1.50013-2

Rosenthal, J.L., Betka, P.M., Nadin, E.S., Gillis, R.J., and Benowitz, J.A., accepted (2017), Vein formation during progressive Paleogene faulting and folding within the lower Cook Inlet basin, Alaska: Geosphere.

Ruppert, N.A., 2008, Stress map for Alaska from earthquake focal mechanisms, in Freymueller, J.T., Haeussler, P.J., Wesson, R.L., and Ekström, Göran, eds., Active tectonics and seismic potential of Alaska: American Geophysical Union Geophysical Monograph Series, p. 351-367. http://doi.org/10.1029/GM179

Savage, H.M., and Brodsky, E.E., 2011, Collateral damage-Evolution with displacement of fracture distribution and secondary fault strands in fault damage zones: Journal of Geophysical Research; Solid Earth, v. 116, no. B3, B03405, 14 p. http://doi.org/10.1029/2010JB007665

Sinclair, S.W., 1980, Analysis of macroscopic fractures on Teton anticline, northwestern Montana: College Station, TX, Texas A\&M University, M.Sc. thesis, $102 \mathrm{p}$.

Solano, N., Zambrano, L., and Aguilera, R., 2011. Cumulative-gas-production distribution on the Nikannassin Tight Gas Formation, Alberta and British Columbia, Canada. SPE Reservoir Evaluation \& Engineering 14, 357-376. http://doi. org/10.2118/132923-PA 
Trop, J.M., and Ridgway, K.D., 1999, Sedimentology and provenance of the Paleocene-Eocene Arkose Ridge Formation, Cook Inlet-Matanuska Valley forearc basin, southern Alaska, in Pinney, D.S., and Davis, P.K., eds., Short notes on Alaska geology: Alaska Division of Geological \& Geophysical Surveys Professional Report 119J, p. 129-144. http://doi.org/10.14509/2692

Trop, J.M., and Ridgway, K.D., 2007, Mesozoic and Cenozoic tectonic growth of southern Alaska-A sedimentary basin perspective: Geological Society of America Special Papers, v. 431, p. 55-94. http://doi.org/10.1130/2007.2431(04)

Trop, J.M., Hampton, B.A, Ridgway, K.D., and Gehrels, George, 2005, Latest Cretaceous sedimentary record of forearc-arc-retroarc relationships in south-central Alaska [presentation]: Geological Society of America Annual Meeting, Salt Lake City, Program with Abstracts, paper no. 31-14, p. 81. https://gsa.confex.com/ gsa/2005AM/finalprogram/abstract_90215.htm

Wartes, M.A., and Herriott, T.M., 2014, A new occurrence of oil-stained rocks within a small fault zone involving the Middle Jurassic Cynthia Falls Formation, Tuxedni Group, northern Iniskin Peninsula, in Gillis, R.J., ed., Cook Inlet program 2013 field studies_-Observations and preliminary interpretations from new 1:63,360scale geologic mapping of the Iniskin Peninsula, lower Cook Inlet, Alaska: Alaska Division of Geological \& Geophysical Surveys Preliminary Interpretive Report 2014-2-5, p. 23-27. http:// doi.org/10.14509/27310

Wartes, M.A., and Herriott, T.M., 2015, Oil-stained sandstone in the Middle Jurassic lower Paveloff Siltstone Member of the Chinitna Formation:
Exploring the potential role of facies variations in controlling diagenesis and reservoir quality in western Cook Inlet, Alaska: Alaska Division of Geological \& Geophysical Surveys Preliminary Interpretive Report 2015-7, 9 p.

Wartes, M.A., Herriott, T.M., Helmold, K.P., and Gillis, R.J., 2013, Preliminary stratigraphic interpretation of the Naknek Formation-Evidence for Late Jurassic activity on the Bruin Bay fault, Iniskin Peninsula, lower Cook Inlet, in Gillis, R.J., ed., Overview of 2012 field studiesUpper Alaska Peninsula and west side of lower Cook Inlet, Alaska: Alaska Division of Geological \& Geophysical Surveys Preliminary Interpretive Report 2013-1H, p. 39-46. http://doi. org/10.14509/24851

Wartes, M.A., Herriott, T.M., Helmold, K.P., Gillis, R.J., LePain, D.L., and Stanley, R.G., 2011, Stratigraphic evidence for Late Jurassic activity on the Bruin Bay fault, Iniskin Peninsula, lower Cook Inlet, Alaska: American Association of Petroleum Geologists Pacific Section Meeting, Anchorage, Alaska, May 10, 2011, p. 96.

Winkler, G.R., 2000, A geologic guide to WrangellSaint Elias National Park and Preserve, Alaska-A tectonic collage of northbound terranes: U.S. Geological Survey Professional Paper 1616, 188 p. https://pubs.usgs.gov/pp/p1616/ Wolfe, J.A., Hopkins, D.M., and, Leopold, E.B., 1966, Tertiary stratigraphy and paleobotany of the Cook Inlet region, Alaska-Discussion of stratigraphic significance of fossil plants from the Chickaloon, Kenai, and Tsadaka Formations: U.S. Geological Survey Professional Paper 398-A, 33 p. https://pubs.er.usgs.gov/publication/pp398A 